\title{
THE ROLE OF CARBON NANOTUBES IN NANOBIOMEDICINES
}

Review Article

\author{
ANAMIKA SAHU1 ${ }^{1}$ AVIRAL JAIN², ARVIND GULBAKE3*
}

1Pharmaceutics Research Laboratory, Department of Pharmaceutics, Adina Institute of Pharmaceutical Sciences, Sagar (M. P.) India, 2Pharmaceutics Research Laboratory, Department of Pharmaceutics, Ravishankar College of Pharmacy, Bhopal (M. P.) 462010, India, ${ }^{3}$ Centre for Interdisciplinary Research, D. Y. Patil University, Kolhapur (M. S.) India

Email: arvind.gulbake@gmail.com

Received: 18 Mar 2017 Revised and Accepted: 20 Apr 2017

ABSTRACT

CNTs is a fullerene molecule, described in 1991 by the Japanese Scientist "Sumio Iijima" as tube-shaped of graphitic carbon, can be obtained either single or multi-walled nanotube, having a diameter measuring on the nanometer scale, and generally known as buckytubes. Carbon nanotubes (CNTs) have established much recent interest as new entities for experimental disease diagnosis and treatment because of their unique electronic, mechanical, thermal, spectroscopic, metallic, semiconducting and superconducting electron transport properties. Carbon nanotubes can be acquired in numerous ways, the general techniques are Arc discharge, Laser ablation, and Chemical vapour deposition (CVD). Carbon nanotubes are discussed in this review in terms of characters, history, structures, properties, synthesis, purification, characterization methods, toxicity and applications. Purification of nanotubes includes many techniques: Acid treatment, oxidation, annealing, ultrasonication, cutting, magnetic purification, chromatography techniques. Further functionalization enhanced the water solubility of CNT's and completely transformed their biocompatibility profile. Carbon nanotubes, due to their large surface areas, unique surface properties, and needle-like shape, can deliver a lot of therapeutic agents, including DNA, siRNAs and proteins to the target disease sites. CNTs can be readily excreted through the renal route by means of degradation through myeloperoxidase (MOP) enzyme. As CNTs have attracted the fancy of many scientists worldwide, the work beyond our expectations and their simple mechanism with long lasting life makes it more reliable to use. The unique and unusual properties of these structures make them a unique material with a whole range of promising applications.

Keywords: Carbon Nanotube, Single-walled carbon nanotubes, Multiwalled carbon nanotubes, Cancer

(C) 2017 The Authors. Published by Innovare Academic Sciences Pvt Ltd. This is an open access article under the CC BY license (http://creativecommons.org/licenses/by/4.0/) DOI: http://dx.doi.org/10.22159/ijpps.2017v9i6.18522

\section{INTRODUCTION}

Pharmaceutical nanotechnology focuses on the top of formulating therapeutically energetic agents in biocompatible nanoforms such as nanoparticles, nanocapsules and conjugates. These systems suggest numerous advantages in drug delivery mainly focusing on better safety and efficiency of drugs i.e., targeted delivery of drugs, improve bioavailability, extending drug or gene effect of drugs, tissue and improving the stability of therapeutic agents in opposition to chemical/enzymatic degradation [1, 2] In the current scenario, nanotechnology is rapidly expanding scientific zone that has achieved a breakthrough in molecular biology, diagnostics, imaging, bioengineering and nanomedicines etc. Carbon nanotubes (CNTs) have established much recent interest as new entities for experimental disease diagnosis and treatment because of their unique electronic, mechanical, thermal, spectroscopic, metallic, semiconducting and superconducting electron transport properties structurally they acquire a hollow core made up of graphite sheets (fig. 1) which are rolled into tubes and are closed at their ends by semi-fullerene like structure [3] (fig. 2) making them appropriate for storing guest molecules as well as their ability to traverse cellular membranes and contain elastic or young's modulus of any recognized materials $[4,5]$ thus seeing much attention as a potent carrier. The sphere-shaped $\mathrm{C}_{60}$ molecule was discovered in 1985 by Harry Kroto and Richard Smally during experiments with laser vaporisation of graphite [6]. Carbon nanotubes were later observed through efforts in fullerene research and were discovered by Sumiolijima in 1991 [4]. The Kroto and Smally group detected the principal generation of $\mathrm{C}_{60}$ and hypothesised that it may exist as a stable closed assembly. Later work by Wolfgang Krätschmer and Donald Huffman developed larger quantities of fullerenes through an arc-discharge process and established the proposed spherical structure of $\mathrm{C}_{60}$ (fig. 3) [7]. Through transmission electron microscopy [8], Iijima scrutinised carbon soot made by the Krätschmer and Huffman method where he found CNTs. The early discovery was of MWCNTs, the smallest being double-walled, and afterwards, discoveries in 1993 independently reported on the first SWCNTs [9]. CNTs are a fullerene molecule was described in 1991 by Sumiolijima as tube-shaped or toroidal shape or cylindrical shells of graphitic carbon, seamless, well-ordered, flat network, high aspect ratio allotropes of carbon having a diameter measuring on the nanometer scale. These carbon-based nanomaterials carbon nanotubes are generally known as buckytubes $[4,10,11]$.

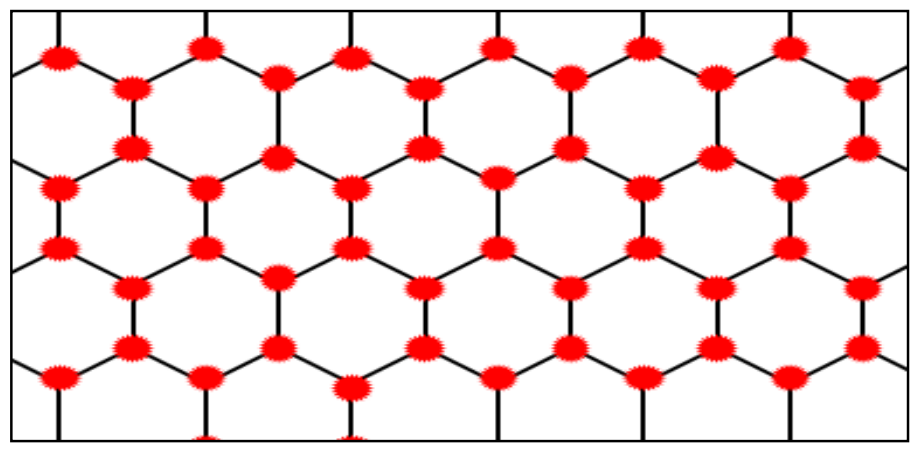

Fig. 1: A single sheet of grapheme 


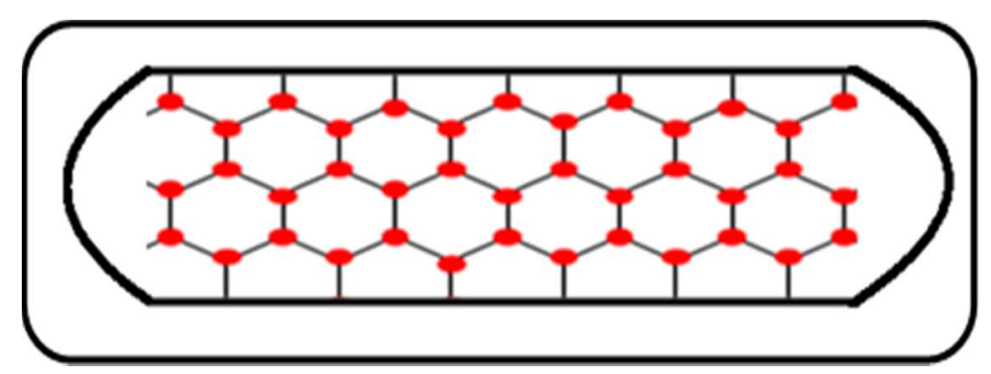

Fig. 2: Carbon nanotubes having ends close with some functional groups of hemi fullerenes

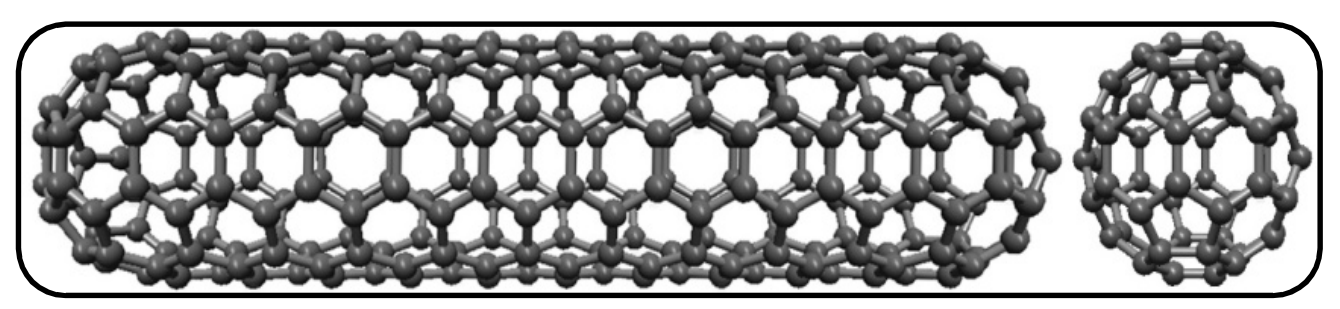

Fig. 3: Carbon nanotube structure demonstrating the resemblance of the end caps to hemispherical $\mathrm{C}_{60}$ molecules shown on the right

The biocompatibility nature, non-immunogenicity, ease of size alteration, greater stability and high drug loading potential makes CNTs a famous tool over the other nanocarriers [12]. Internal and external surfaces of CNTs can be modified on an individual basis as required and a variety of functional groups can be generated on their surface in support of further conjugation with targeting ligands as well as drug molecules[13]. There are two types of carbon nanotubes, distinguished in (table 1):-

$\checkmark$ Single-walled carbon nanotubes (SWCNT's)

$\checkmark$ Multi-walled carbon nanotubes (MWCNT's)

Table 1: Types and properties of CNT's

\begin{tabular}{lll}
\hline $\begin{array}{l}\text { Types } \\
\text { Structure }\end{array}$ & $\begin{array}{c}\text { Single-walled carbon nanotubes } \\
\text { SWCNT }\end{array}$ & \multicolumn{1}{c}{ Multi-walled carbon nanotubes } \\
& & \\
& &
\end{tabular}

MWNTs may also be fabricated by SWNTs of distinct diameters. SWNTs are hollow cylindrical structures may be separated into three different categories, each of which is a couple of fullerene caps connected by a tube-shaped structure that is a rolled up into the seamless graphene sheets. Various important carbon nanomaterial structures (fig. 4). SWNTs are composed of a single atomic layer of graphite, having a different chirality. They are: (A) Zigzag,(B) Chiral, (C) Armchair (table 2)[15]. Carbon nanotubes (CNT's) own high specific surface areas, electrical conductivities, chemical stability, etc. which could be achieved by the treatment of CNT with acid [1617] (fig. 5) and named as refluxing. CNTs also enhance the electron transfer rate of many redox reactions [18].

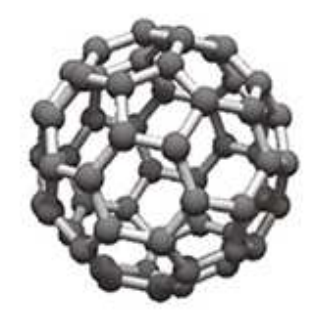

Fullerene $\left(\mathrm{C}_{60}\right)$

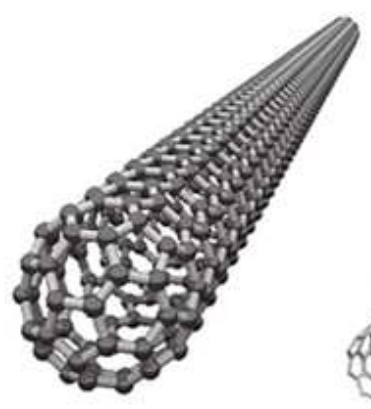

SWCNT

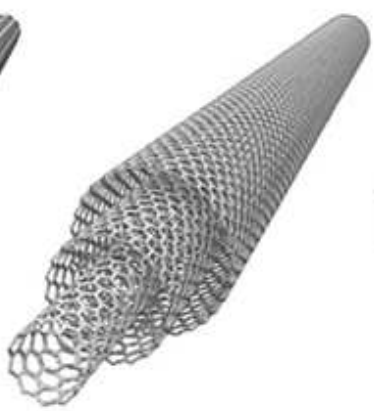

MWCNT

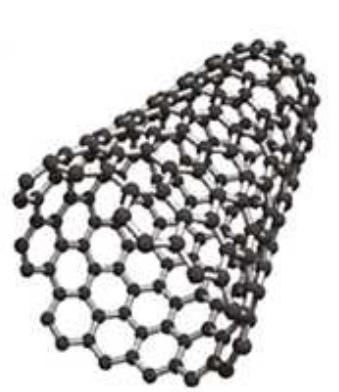

Carbon nanohorn

Fig. 4: Structures of various important carbon nanomaterials: Fullerene $\left(\mathrm{C}_{60}\right)$, Single-Walled Carbon Nanotube (SWCNT), Multi-Walled Carbon Nanotube (MWCNT) and Carbon Nanohorn 


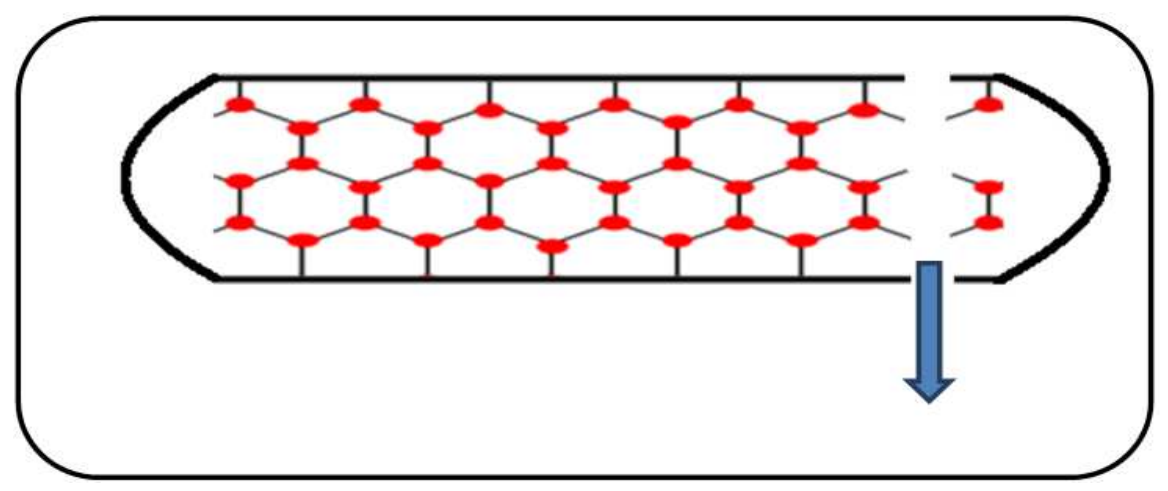

Fig. 5: Open carbon nanotube by the action of an acid

Table 2: Types of SWCNTs

\begin{tabular}{lll}
\hline Types & Categories & Properties \\
\hline $\begin{array}{l}\text { 1. } \\
2 .\end{array}$ & $\begin{array}{l}\text { Zigzag } \\
\text { Chiral }\end{array}$ & $\begin{array}{l}\text { Named after the pattern of the hexagon as one moves circumferentially around the body of the tubule. } \\
\text { Most commonly occurring SWNT. } \\
\text { Chiral-means handedness and indicates that the tubes may twist in either direction. } \\
\text { Describe one of the two conformers of Cyclohexane, ahexagon of carbon atoms and, Describe the } \\
\text { shape of the hexagons as one move around the body of the tubules. }\end{array}$ \\
\hline
\end{tabular}

\section{Structures}

\section{Bonding}

The $\mathrm{sp}^{2}$ hybrid orbital permit's carbon atoms to form hexagons and occasionally pentagons and Pentagon units through in-plane $\sigma$ bonding and out-of-plane $\pi$ bonding.

\section{Defect-free nanotubes}

These are tubular structures of a hexagonal network having a diameter as small as $0.4 \mathrm{~nm}$. Tube-shaped curvature gives results in $\sigma-\pi$ rehybridization or mixing.

\section{Defective nanotubes}

Occasionally, pentagons and heptagons are included into a hexagonal network to form bent, choroidal, branched, helical, or capped nanotubes [19].

\section{Properties}

The unique properties make CNTs very useful for supporting noblemetal nanoparticles. Metal-nanoparticle/CNT nanohybrid has many potential applications ranging from highly-developed sensors to highly efficient fuel cells [20]. CNTs are very light tubular nanomaterials with a great aspect ratio (length/diameter), huge payload capacity with rich surface chemistry for functionalization [21,22].

\section{Physical properties}

Orientation and diameter of the nanotubes can affect the physical properties of nanotubes to a great degree. These have hexagonal carbon lattices relative to the central CNT axis [23], which can be lined up according to the purpose [10].

\section{Electrical}

Electron confinement along the tube perimeter makes defect-free nanotubes either semiconducting or metallic by quantized conductance whereas pentagons and heptagons will generate localised states.

\section{Optical and optoelectronic}

One-dimensional band structure and direct band gap make nanotubes ideal for optical applications with a wavelength ranging possibly from 300 to $3000 \mathrm{~nm}$.

\section{Mechanical and electromechanical}

$\sigma-\pi$ rehybridization gives nanotubes the highest Young's modulus of over one $\mathrm{TPa}$ and tensile strength of over $100 \mathrm{Gpa}$ and significant electronic response to strain and metal-insulator transition.

\section{Magnetic and electromagnetic}

Electron orbits circulating around a nanotube provide rise to many attention-grabbing phenomena such as quantum oscillation and metal-insulator transition.

\section{Chemical and electrochemical}

$\sigma-\pi$ rehybridization and high specific surface make possible molecular adsorption, doping, and charge transfer on nanotubes, which, in turn, modulates electronic properties.

\section{Thermal and Thermoelectric}

Hereditary from graphite, nanotubes to display the highest thermal conductivity while the quantum effect [19].

\section{Growth mechanism and synthesis of carbon nanotubes}

The techniques are not known exactly for the formation of the nanotube and more than one method of growth mechanism might be effective for the construction of carbon nanotubes is still a conflict. The mechanism comprises the steps shown in (fig. 6) and the simple diagrams of growth mechanism shown in (fig. 7). Firstly, $\mathrm{C}_{2}$ acts as a precursor for the construction of nanotubes and fullerenes on the surface of the metal catalyst particle.

A rod-like carbon is producing quickly from metastable carbide particle. Secondly, CNT's wall contributes to slow graphitisation. For all technique nanotubes, actual growth mechanism seems similar [24]. On a growth mechanism of nanotubes, there are several theories one of which describes in (fig. 6), for supported metals, filaments can form either by 'extrusion/root/base growth' or by 'tipgrowth'. Catalyst size plays a role in the type of nanotube obtained whether SWNTs or MWNTs.

(A) Particles of metal catalyst are supported or floating on graphite or on a different substrate, which anticipates the spherical or pearshaped of the catalyst particles.

(B) The deposition will occur only on one-half of the surface and the carbon diffuses along the concentration gradient and precipitated on the opposite half, around and below the bisecting diameter, it does not take part from the tip of the hemisphere, which accounts for the vacant core that is distinctive of these filaments.

(C) Extrusion or root growth: nanotube grows upwards from the metal particles that remain attached to the substrate.

Tip growth: the particles detach and move at the head of the growing nanotube. 


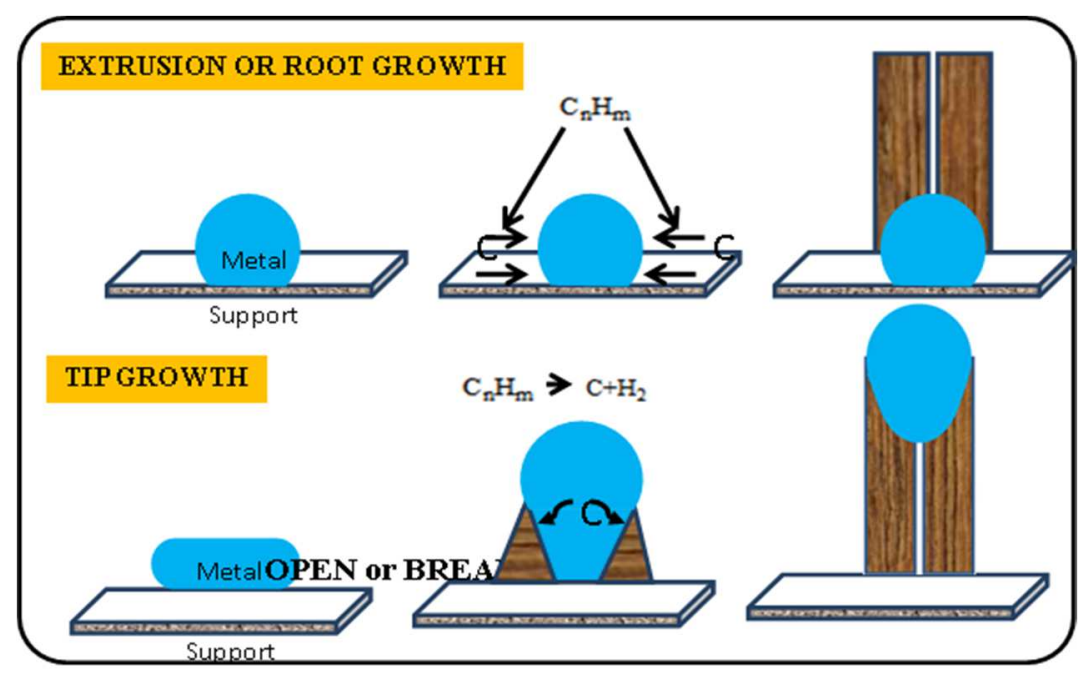

Fig. 6: The visual image of a possible carbon nanotube growth mechanism

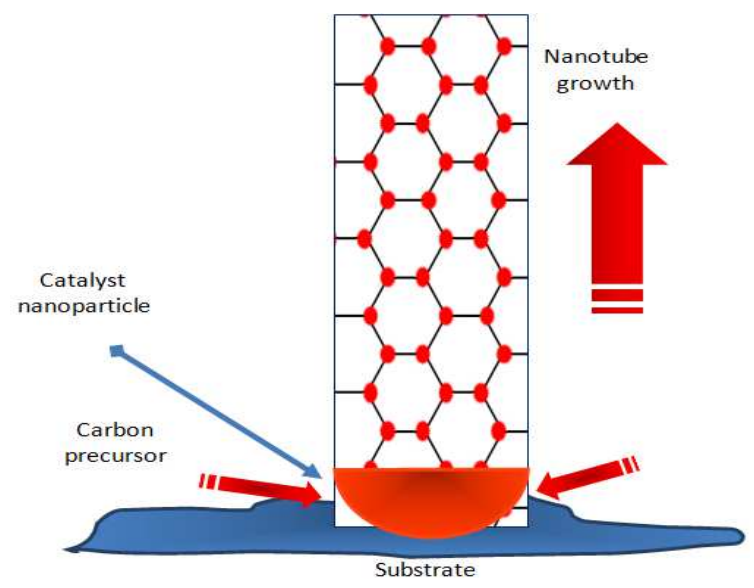

Fig. 7: Growth mechanism of nanotubes: gas based on carbon breaks apart on the surface of the catalyst by CVD, and nanotube grows outwards from the surface

\section{Synthesis}

CNT is generally produced by three main techniques:

Arc-discharge: Two electrodes of carbon in presence or absence of catalyst are taken, and an arc is discharged between them. Resulting vapours of carbon get self-assembled and give rise to nanotubes (fig. 8) $[25,9,26]$.
Laser ablation: Collision occurs between the high-power laser pulse and volume of carbon, which contains the methane or carbon monoxide as a feedstock gas and produce nanotubes in small quantity (fig. 9) $[23,27,28]$.

Chemical Vapor deposition (CVD): Produce MWNT's or SWNT's of poor quality and range of large diameter. CVD process is scaled up easily and favours the viable manufacture (fig. 10) [24].

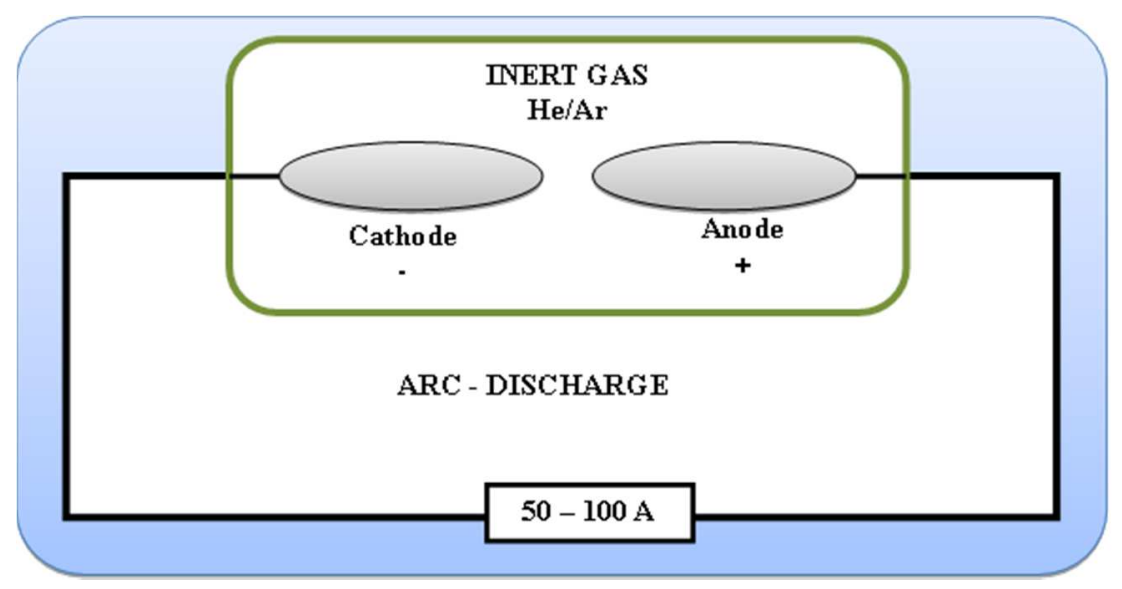

Fig. 8: Diagrammatic representation of arc discharge setup for synthesis and growth of the nanotube 
From above three main methods, CVD shows the most prospective for commercial CNT production [29]. In summation to enabling higher atomic quality and percent yield than the other methods [30], CVD provides manufacturers with control over nanotube orientation, length, diameter and other parameters [31]. CVD is capable of making bulk quantities of multi-walled nanotubes for composites or individual, aligned SWNTs on substrates for utilise in electronics [9]. A brief description of methods contributing to the mass production with their effectiveness is given in fig. 11.

A summary of the major production methods of carbon nanotubes and their efficiency described in table 3.

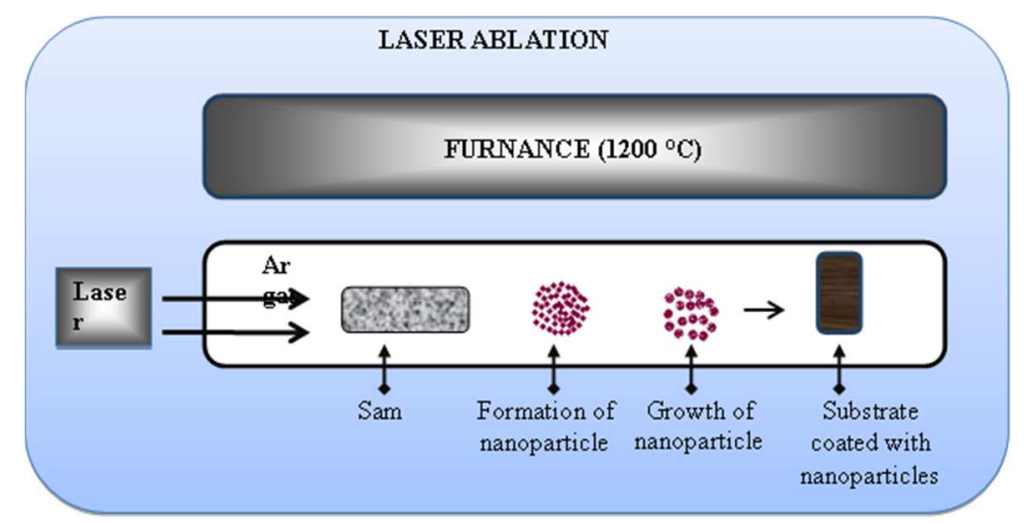

Fig. 9: Diagrammatical representation of laser ablation setup for nanotube synthesis and growth

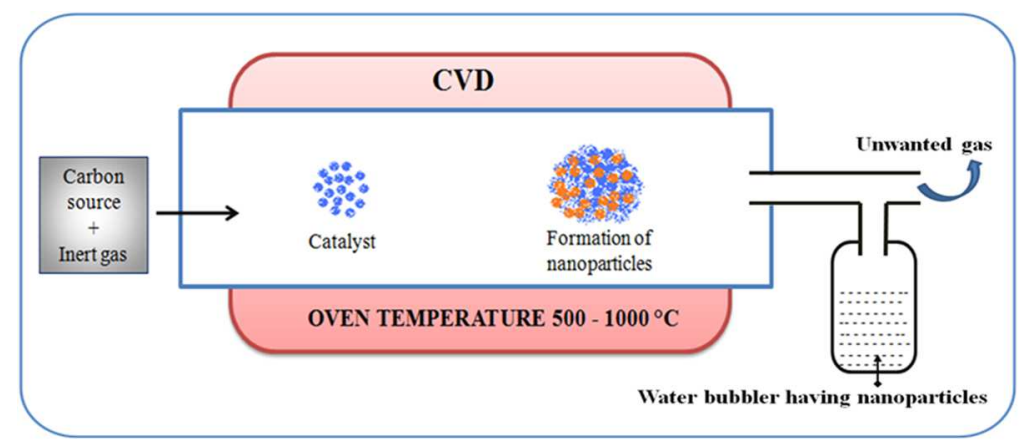

Fig. 10: Diagrammatical representation of chemical vapor deposition (CVD) setup for nanotube synthesis and growth

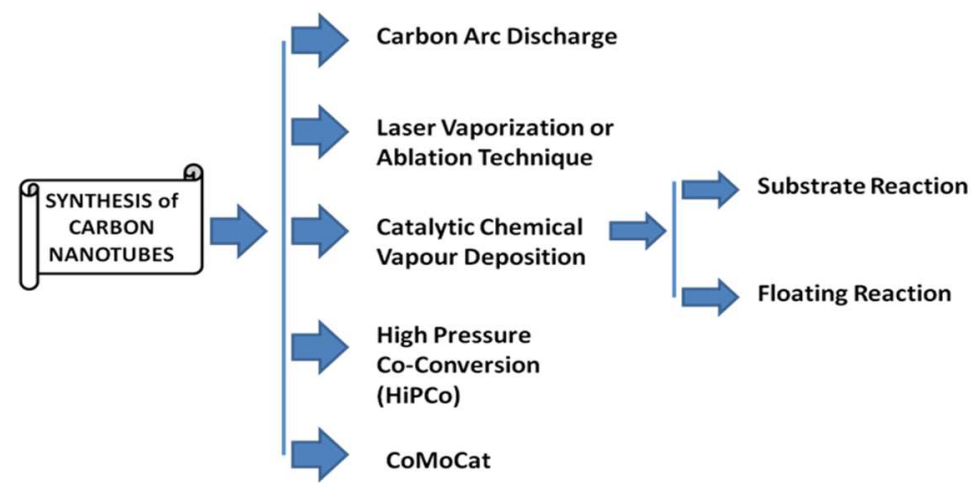

Fig. 11: Methods of synthesis for carbon nanotubes

\section{Purification}

The physicochemical properties such as surface topography, solubility, hybridization state, mechanical properties, thermal conductivity, and structural and metallic or carbonaceous impurities, of CNTs, have to be evaluated for biomedical applications [36]. Purification is the primary step and is always needed before any further use of CNTs. Prepared CNTs contain an assortment of impurities that are essential to be removed prior to their utilisation in drug, gene or vaccine delivery. Zhao et al. 2001 [37] reported on the numerous approaches that may be utilised for purifying the prepared CNTs that involve filtration, microfiltration, centrifugation, chromatography, annealing, flocculation, oxidation of contaminant, ferromagnetic separation, functionalisation, ultrasonication, selective interaction with organic polymers, cutting, sedimentation and microwave irradiation. These purification techniques enhance the nanotube solubility, which is easier to separate from the insoluble impurities[38, 39]. CNT products contain substantial amounts of metal impurities and non-nanotube carbon. These are vanished by post-manufacturing treatments, and three fundamental methods have been reported for purification they are:

a) Gas phase [40],

b) Liquid phase [41], and 


\section{c) Intercalation techniques [42].}

The occurrence of such metal impurities might lead to a variety of adverse biological end-points [43]. Wrapped up graphite sheets, small fullerenes, catalyst, etc. contributes for the major impurities which can interfere with the required properties of the CNT's, generally as the diameter decreases, impurities increases[39]. Homogenous CNT's samples are of much interest, which can be achieved by refluxing and oxidation technique[24]. Several purification techniques of the SWNT are basically, studied under two heads viz., structure dependent and size dependent separations.

The structure dependent purification techniques will separate the impurities on the basis of the difference in the structure of the carbon nanotubes and impurities while the size dependent separation techniques yield a uniform distribution of size.

Table 3: Production methods of carbon nanotubes and their efficiency

\begin{tabular}{|c|c|c|c|c|}
\hline Method & Arc discharge method & Chemical vapor deposition & Laser ablation (vaporization) & Ref \\
\hline Who & Ebbesen and Ajayan, NEC, Japan 1992 & $\begin{array}{l}\text { Endo, Shinshu University, Nagano, } \\
\text { Japan }\end{array}$ & Smalley, Rice, 1995 & $\begin{array}{l}{[19,} \\
32, \\
33]\end{array}$ \\
\hline Process & $\begin{array}{l}\text { The first carbon nanotubes were } \\
\text { developed with the arc-discharge } \\
\text { method with no use of metal catalysts, } \\
\text { producing MWCNTs [7]. Arc- } \\
\text { vaporization of two carbon rods } \\
\text { placed end to end, separated by } \\
\text { approximately few millimetres apart } \\
\text { ( } 1 \text { mm), in an enclosure that is usually } \\
\text { filled with inert gas at low pressure. A } \\
\text { direct current of } 50 \text { to } 100 \text { Amps, } \\
\text { driven by a potential difference of } \\
\text { approximately } 20 \text { V creates a high- } \\
\text { temperature discharge between the } \\
\text { two electrodes. The discharge } \\
\text { vaporises the surface of one of the } \\
\text { carbon electrodes and forms a small } \\
\text { rod-shaped deposit on another } \\
\text { electrode. } \\
\text { Primarily used to produce C } 60 \\
\text { fullerenes, is the easiest and common } \\
\text { way to produce CNTs. }\end{array}$ & $\begin{array}{l}\text { Chemical Vapor Deposition of } \\
\text { hydrocarbons over a metal catalyst is a } \\
\text { standard method that has been used to } \\
\text { produce various carbon materials like } \\
\text { carbon fibers and filaments. A lot of } \\
\text { CNTs can be produced by catalytic CVD } \\
\text { of acetylene over iron and cobalt } \\
\text { catalysts supported on zeolite or silica. } \\
\text { High yields of single-walled nanotubes } \\
\text { have been obtained by catalytic } \\
\text { decomposition of theH } \mathrm{CH}_{4} \text { mixture } \\
\text { all over well-dispersed metal particles } \\
\text { such as nickel, cobalt and iron on } \\
\text { magnesium oxide at } 1000^{\circ} \mathrm{C} \text {. The } \\
\text { reduction produces miniature } \\
\text { transition metal particles at a } \\
\text { temperature of usually> } 800^{\circ} \mathrm{C} \text {. The } \\
\text { decomposition of } \mathrm{CH}_{4} \text { over the freshly } \\
\text { formed nanoparticles prevents their } \\
\text { further growth and thus results in a } \\
\text { very high proportion of SWNTs and } \\
\text { few MWNTs. }\end{array}$ & $\begin{array}{l}\text { In Laser ablation laser vaporisation pulses } \\
\text { were followed by a second pulse, to } \\
\text { vaporise the target (graphite/carbon) } \\
\text { more uniformly while an unreactive gas } \\
\text { permeates the reaction chamber. The use } \\
\text { of two successive laser pulses (rather than } \\
\text { electricity) minimises the amount of } \\
\text { carbon deposited as soot. The second } \\
\text { laser pulse breaks up the larger particles } \\
\text { ablated by the first one and feeds them } \\
\text { into the growing nanotube structure. The } \\
\text { material produced by this method appears } \\
\text { as a mat of "ropes". }\end{array}$ & $\begin{array}{l}{[19,} \\
34 \\
35]\end{array}$ \\
\hline $\begin{array}{l}\text { Typical } \\
\text { yield }\end{array}$ & 30 to $90 \%$ & 20 to $100 \%$ & Up to $70 \%$ & [28] \\
\hline SWNT & $\begin{array}{l}\text { Formation of Short tubes with } \\
\text { diameters of } 0.6-1.4 \mathrm{~nm}\end{array}$ & $\begin{array}{l}\text { Formation of Long tubes with } \\
\text { diameters ranging from } 0.6-4 \mathrm{~nm}\end{array}$ & $\begin{array}{l}\text { Formation of Long bundles of tubes ( } 5-20 \\
\text { microns), with individual diameter from } \\
1-2 \mathrm{~nm} \text {. }\end{array}$ & \\
\hline MWNT & $\begin{array}{l}\text { Formation of Short tubes with inner } \\
\text { diameter of } 1-3 \mathrm{~nm} \text { and outer } \\
\text { diameter of approximately } 10 \mathrm{~nm}\end{array}$ & $\begin{array}{l}\text { Formation of Long tubes with diameter } \\
\text { ranging from } 10-240 \mathrm{~nm}\end{array}$ & $\begin{array}{l}\text { Not so much interest in this technique, } \\
\text { seeing that it is too expensive, but MWNT } \\
\text { synthesis is possible. }\end{array}$ & \\
\hline $\begin{array}{l}\text { Gaseous } \\
\text { carbon } \\
\text { sources }\end{array}$ & Helium, argon & $\begin{array}{l}\text { Methane }\left(\mathrm{CH}_{4}\right) \text {, carbon monoxide } \\
\text { and acetylene }\end{array}$ & $\mathrm{NH}_{3}$ gas & \\
\hline Merits & $\begin{array}{l}\text { Can easily produce MWNTs, SWNTs. } \\
\text { SWNTs have fewer structural defects; } \\
\text { MWNTs without a catalyst, not too } \\
\text { expensive, open air synthesis possible. }\end{array}$ & $\begin{array}{l}\text { Easy to scale up to industrial } \\
\text { production; long length, simple } \\
\text { process, SWNT diameter controllable, } \\
\text { quite pure. }\end{array}$ & $\begin{array}{l}\text { Primarily SWNTs, with good diameter } \\
\text { control and few defects. } \\
\text { The reaction product is quite pure. }\end{array}$ & \\
\hline
\end{tabular}

\section{Methods of purification}

\section{Oxidation}

Carbon based impurities and surface metal can be taken away by the oxidative treatment [44-51]. But this may lead to the oxidation of nanotubes along with the impurities. Still, the method is preferred because the damage caused to the nanotubes is comparatively less than that of the impurities and the metal catalyst also serves as the oxidising agent $[45,52,53,35]$. Metal content, time of oxidation, an oxidising agent and environmental factor including temperature are the common process variable which affects the yield of the process. For example, when the temperature is raised to $600{ }^{\circ} \mathrm{C}$, SWNTs will oxidise, even without a catalyst, This happens in the case with thermal [45], pure oxygen oxidations [35, 46] and fixed air $[35,51]$. These can oxidise all the component without many efforts so as to have better control of time and temperature [35]. Several examples for clearing the metal surface as well as to prepare the sample for a metal removal step. Firstly the mild oxidation with soluble oxidising agents in the wet environment, such as $\mathrm{H}_{2} \mathrm{SO}_{4}$ and $\mathrm{H}_{2} \mathrm{O}_{2}$, which oxidise the defects along with clearing the metal surface [35]. Throughout these processes the metal catalyst stays together, the outer layer of the metal will be oxidised when oxygen is used in the wet atmosphere [35]. After that the density of surface increases and deposit of surface covering carbon ruptures. Now not only the carbon impurities are oxidised but the metal is also partially oxidised and exposed.

\section{Acid treatment}

Acid treatment: It removes the metal catalyst by exposing the metal surface to oxidation or sonication. Then the metal catalyst is exposed to acid and solvated so that the nanotubes remain in the suspended form. When $\mathrm{HNO}_{3}$ is used for the treatment, it only affects the metal catalyst but not the nanotubes or other particles of carbonaceous nature $[45,48,49]$. With HCL, less effect on single-walled carbon nanotubes and other carbon particles were observed during reflux but unlike $\mathrm{HNO}_{3}$, metal should be exposed to acid so that lysis of graphitic carbon and short fullerenes. The metal will be melted and can be removed by using vacuum having high-temperature $[50,53,45,46]$. 


\section{Annealing}

Annealing: High temperature between $873 \mathrm{~K}-1873 \mathrm{~K}$ will result in the rearrangements of nanotubes with the consumption of defects resulting in the pyrolysis of graphitic carbon and short fullerenes. The metal will be melted and can be removed by using vacuum having high temperature $[54,53,46]$.

\section{Ultrasonication}

Sonication is well-known as one of the effectual processes to get rid of the amorphous impurities adhering or binding to the walls of CNTs using suitable solvents $[50,55]$. During sonication, the solvent molecules are able to interact with CNTs and hence lead to solubilization, which can improve purification efficiency [56]. In ultrasonication, vibration caused by sonic waves result in separation of particles and dispersion of nanoparticles agglomerates. Separation of the particles depends on the solvent, surfactant and reagent used. Stability of the dispersed tubes is influenced by the solvent, if the solvent is poor and attached to the metal SWCNT's are more stable, but solvent like alcohol, mono-dispersed particles are comparatively stable $[39,45,49,52,54]$. Ultrasonication in ethanol was adopted to remove the graphite particles [57]. The purity of the nanotubes depends on the exposure time. When an acid is used and if the exposure time is less, only metal get solvates but if the time is long, it will result in cutting down of the tubes $[39,46]$.

\section{Cutting}

The nanotubes can be shortened or cut by three steps, chemically, mechanically and the combination of both.

a) Chemically-Chemicals are used for cutting of CNTs. After partially functionalizing the CNTs followed by the pyrolisation in the form of $\mathrm{CF}_{4}$ or $\mathrm{COF}_{2}$ fluorated carbon will be driven off the sidewall which leaves behind the nanotubes those are chemically cut [48].

b) Mechanically: Due to high friction between the nanoparticles and the nanotubes the bonds will break and disordered and the cutting is caused by ball-milling [55].

c) The combination of both (chemically and mechanically): In an acid solution cutting of the nanotubes is ultrasonically induced, thus the ultrasonic vibration will provide the sufficient energy for the nanotubes to leave the catalyst surface [58]. After that, the nanotubes will rupture at the defect sites in combination with an acid.

\section{Magnetic Purification}

Magnetic Purification-Removal of ferromagnetic (catalytic) particles occurs mechanically from their graphitic shells. To get rid of these ferromagnetic particles in an ultrasonic bath the SWNTs suspension and inorganic nanoparticles ( $\mathrm{ZrO} 2$ or $\mathrm{CaCO} 3$ ) were mixed together, followed by the trapping of particles by stable magnetic poles. Since SWNT of high purity will be obtained by chemical treatment [48] (fig. 12). Large equipment is not required, and it has been observed that the production of laboratory-sized quantities of SWNTs containing no magnetic impurities [59].

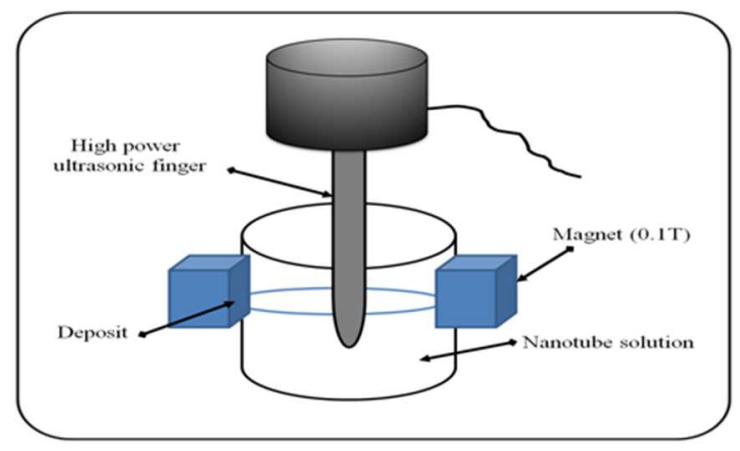

Fig. 12: Magnetic purification apparatus

\section{Chromatography}

To separate the CNTs in relation to small length and diameters the chromatography is mainly used. The carbon nanotubes with the porous material are run through a column, through which CNTs will pass. The GPC (Gel Permeation Chromatography) and HPLC-SEC (High-Performance Liquid Chromatography-Size Exclusion Chromatography) columns are some examples which are used in the technique of separation. According to the size of molecules, they get separated with the large size of molecules eluting out first. The only requirement is that the nanotubes should be either solvated or dispersed by means like functionalization and ultrasonication [60].

\section{Limitations and modification (functionalization)}

Pristine CNT's(non-functionalized) is inherently hydrophobic, and readily aggregate in bundles due to van der Waals forces [61] and, therefore, the main barrier in the utilisation of CNT in biology and medicinal chemistry is their lack of solubility in most solvents compatible with the biological milieu (aqueous based). To defeat this problem the several ways existing, numerous strategies have been invented with different molecules is achieved by adsorption, electrostatic interaction or covalent bonding of different molecules and chemistries that make carbon nanotubes more hydrophilic and soluble [62]. The limitation in the applications of CNT's can be defeated, to some extent, by a process named functionalization [32]. Functionalization of CNTs can be achieved in two ways shown in (fig. 13).

1. Non-Covalent Functionalization-Various non-covalent interactions, for example, $\pi$ stacking, hydrophobic and van der Waals interactions have allowed for the functionalization of CNTs with a wide range of molecules.

2. Covalent Functionalization-May be described as a chemical grafting of molecules onto the $\mathrm{sp}^{2}$ carbon atoms of the $\pi$-conjugated skeleton of the CNTs. The basic reaction for CNT functionalization is oxidation [63], performed under strongly acidic conditions. There are two main strategies for covalently functionalizing nanotubes:

a) End and defect modification and

b) Sidewall modification.

These covalent modifications arise from the difference in reactivity at the nanotube ends and sidewalls (as well as at structurally perturbed areas) and, accordingly, each type of functionalization requires distinct chemical approaches [64-69].

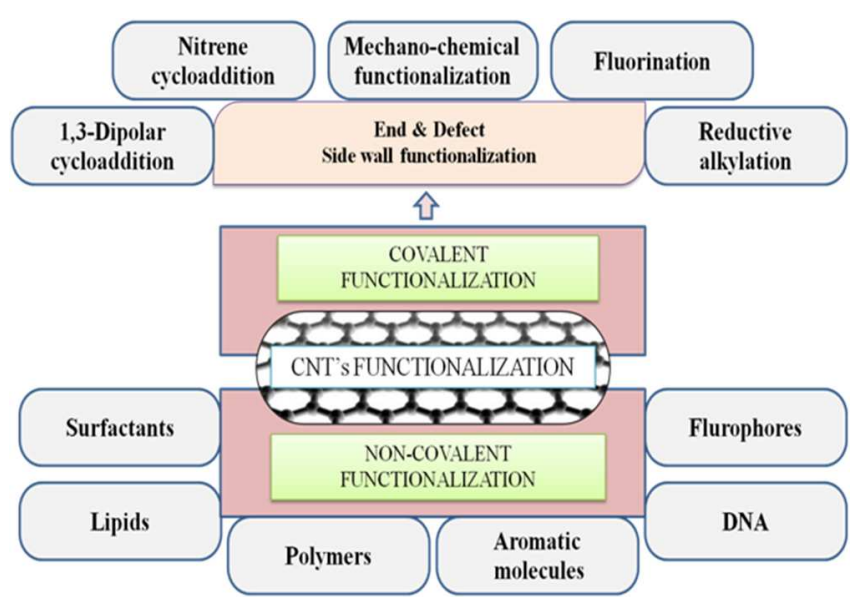

Fig. 13: Approaches for CNT functionalization

a) Ends And Defects- Ends of the CNT's are more reactive than the sidewalls. Treating the CNTs with oxidative agents results in introducing oxygenated groups, for instance, carboxylic acid, ketone, alcohol, and ester, at the nanotube ends and defect sites [70](fig. 14), thus leaving the ends open and possibly cutting and shortening CNTs [71]. Such treatments eliminate amorphous carbon and metal catalyst particles and can remove smaller diameter (more reactive) tubes. Techniques have been developed to probe the degree of oxidation and the type of oxygenated groups formed [72]. Oxidation also results in hole-doping of the CNTs causing disruption of its 
electronic structure, [73] though the disruption is less pronounced than those produced in the case of sidewall modification, as discussed in (fig. 14).

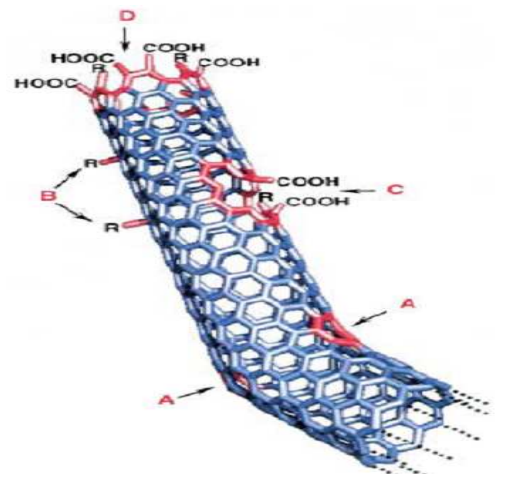

Fig. 14: Typical sites for ends and defect oxidation of MWCNT's. A) five-or seven-member rings instead of the normal hexagons, leads to a bend in the tube, B) sp3-hybridized defects such as $\mathrm{R}$ ? $\mathrm{H}$ and $\mathrm{OH}, \mathrm{C}$ ) damage by oxidative conditions, D) open and oxidised ends

Other modifications of oxidised CNTs by non-covalent interactions have also been performed through zwitterionic interactions and nonspecific protein binding [74], which have coupled CNTs to crown ether [75]. The common reactions employed for further covalent modification are summarised in (fig. 15).

b) Sidewall Functionalization-To introduces higher concentrations of covalently attached functional groups onto the surface of CNTs with the substitution of significant disruption in the electronic structure or the method used to break down the bonds present on the wall of CNTs which helps to attach the different functional groups. These types of reactions are summarised in (fig. 16).

Thus, functionalization heightens the scope of CNTs as raising nano vectors for the delivery of therapeutics [76]. Through surface functionalization, the water solubility of CNT is enhanced and their biocompatibility profile is completely transformed. Because CNT's are soluble in water, they were aggregate in the presence of salts, due to charge screening and therefore, cannot be directly used in biological applications due to the high salt content of most physiologic media. Hence, a further modification is needed, e. g., binding with hydrophilic polymers, such as polyethylene glycol (PEG) and forming CNT-polymer conjugates, which are stable in physiological environments [77]. The drawback of this method is that it results in the partial loss of electronic structure and optical properties of the CNTs and a loss of material, due to the oxidative process [78], [79]. On the other hand, these issues are of less importance in drug-delivery applications.

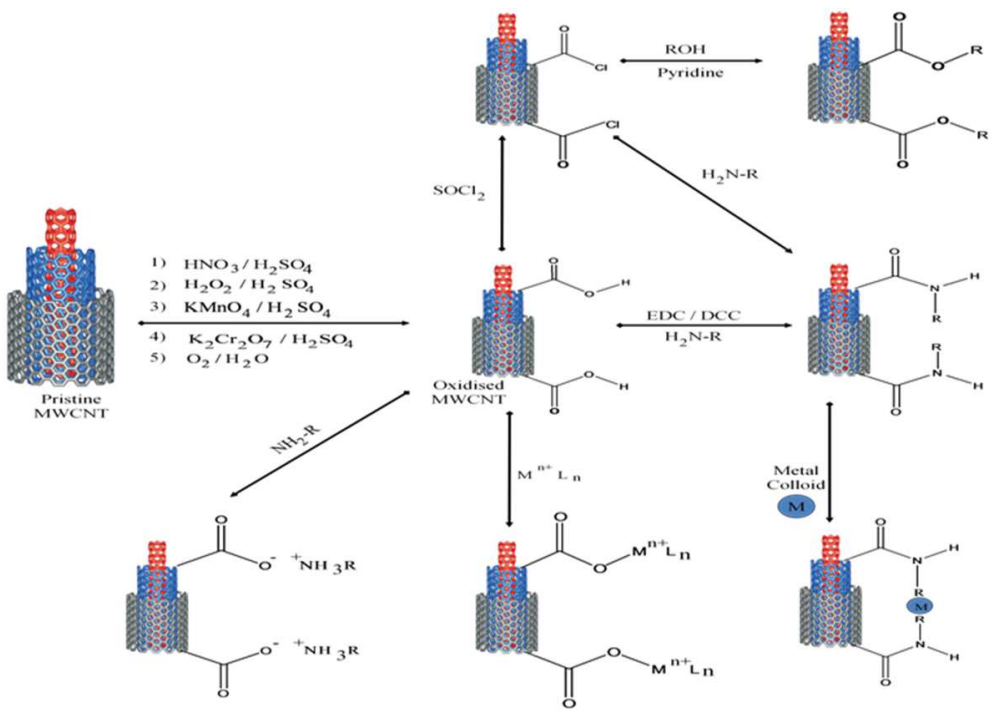

Fig. 15: Common strategies for covalent functionalization of CNT's via ends and defect site oxidation

\section{Characterization}

Carbon nanotubes are nanometric carbon particles, but it also contains many of the impurities. Characterization of CNTs headed for determination of the quantity, quality, and properties of the CNTs sample which is very important, because its applications will require certification of properties and function.

\section{Electron microscopy (EM)}

Electron microscopy (scanning and transmission electron microscopy) is an essential tool for characterising any nanomaterial it gives direct observation of size, shape, and structure [80]. Various techniques of electron microscopy, one can easily study on the CNT structures and identify their growth mechanism, which helps in modifying their structure and improves the growth process[15].

\section{Scanning electron microscopy [81]}

SEM images the sample morphology by scanning the surface with a high-energy beam of electrons. It is the first step to characterise the CNTs. Using SEM, the morphology of CNTs, their dimensions and their orientations can readily be seen [19], [27], [82]. Diameters of
CNTs also can be measured roughly with SEM [83]. Chains of singlewalled nanotubes (SWNT's) in a sample, as well as highly oriented MWNT's, can be imagined by SEM using quartz or silicon substrates. Impurities like carbon-coated catalyst particles or amorphous carbon co-existing with nanotubes bundles and the tubular onedimensional (1-D) structure of the MWNTs can also be determined more accurately using SEM as compare to other techniques [84].

\section{Transmission electron microscopy [8]}

The internal microstructure and crystal structure of samples which are thin enough to transmit electrons can be analysed with TEM. It is used to measure outer and inner radius and linear absorption coefficient for CNT studies [60], effects of nitrogen doping in MWNTs and SWNT peapod structures are a few to name, which can be investigated by TEM. It also identifies various layers of MWCNTs and separates SWNTs from the bundles. This stands for analysis of morphological structure and diameter measurement of carbon nanotubes [84]. The composition of catalyst detection responsible for nanotube nucleation enabled by TEM in conjugation with X-ray energy dispersive spectroscopy [84, 85]. Electron diffraction and electron energy loss spectroscopy (EELS) along with TEM has the 
advantage that the average helicity and local variation of helicity in individual SWNT and ropes of SWNT's can be determined on the nanoscale. EELS help researchers to find out the amount of dopant present in doped nanotube structure [86].

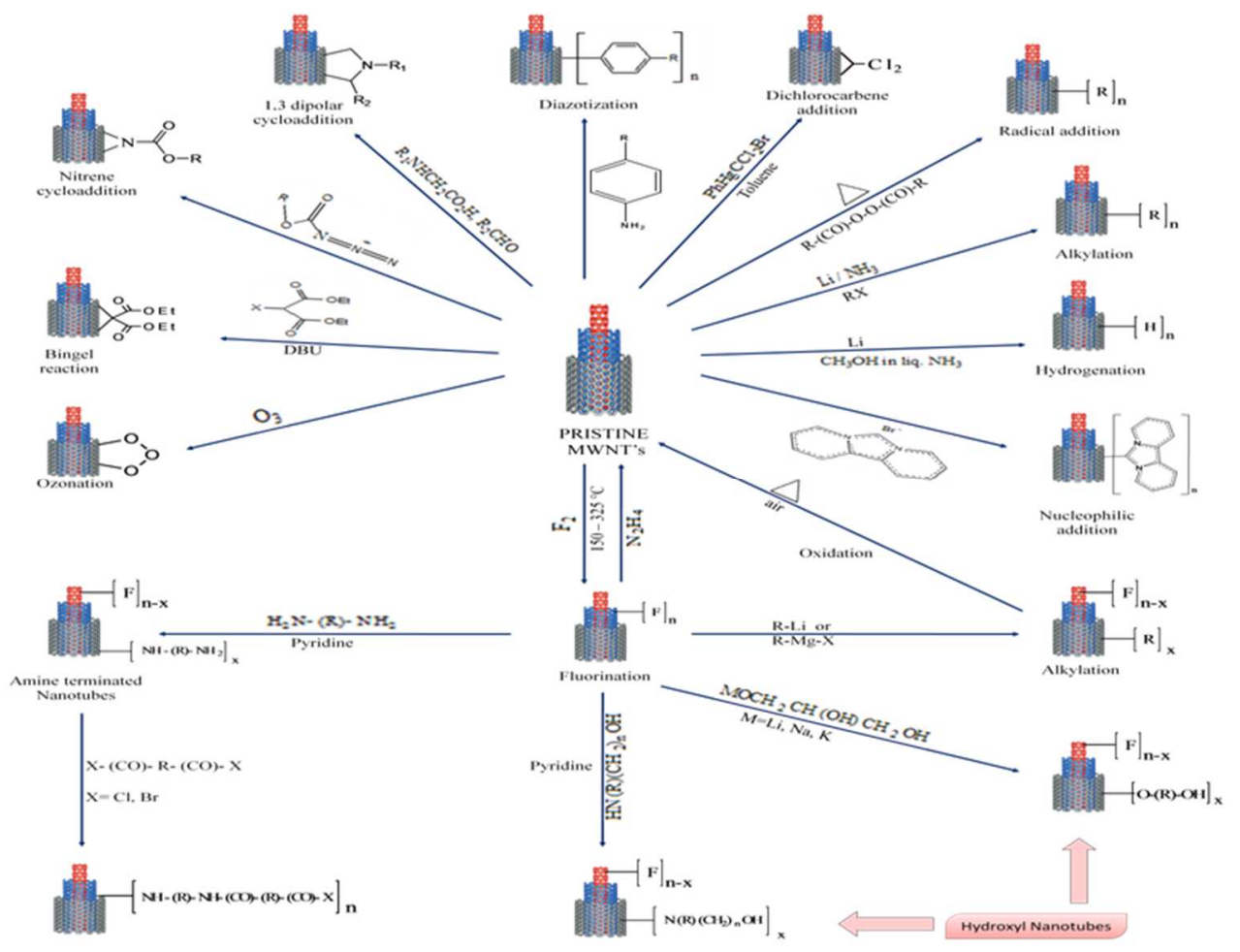

Fig. 16: Strategies for covalent sidewall functionalization of CNT's

\section{Scanning tunnelling microscopy (STM) and atomic force microscopy (AFM)}

These techniques provide morphologic information and properties (fundamental) of the nanotubes, which are vital in the research field of nanotubes. AFM is valuable in visualising isolated carbon nanotubes, which grows on the substrate of silicon by the process of either treating the nanotube bundles or chemical vapor deposition $[31,87,88]$, [89]. Because of flexible nature and one-dimensional character of carbon nanotubes, they are used as AFM as well as STM tips as these properties help them to endure a crash into a sample with no/little damage to the tip, but only requirement for STMnanotube tip is that the sample should essentially be grown on a conducting surface [90].

\section{Raman spectroscopy}

For the characterization of carbon-based materials, Raman's spectroscopy is an equally valuable method and is applied to study the properties and quality of metallic, superconducting and pristine phases of graphite intercalation compound and solids based on fullerene [60]-[91]. Inelastic light scattering from nanotubes cause's increase or decrease in an incident light energy because of emission or absorption of the photon thereby resulting in scattering known as Raman scattering [92]. This technique gives information with details about configuration of CNTs. A number of walls, the presence of crystalline and amorphous carbon and diameter of SWNTs can be determined with the Raman spectroscopy. Without sample preparation, a fast and nondestructive analysis is possible [60]. In this spectroscopy when a beam of light passes through a transparent sample of a chemical compound, a small part of the light emerges in different directions than the incoming beam. Most of these scattered lights are of unchanged wavelength, however, a small part has wavelengths different from the incident light, and its presence is a result of Raman Effect. The pattern of the Raman spectrum is characteristic for every molecular species and the intensity is proportional to the number of scattering molecules in the path of the light. Resonance peaks are also observed in the spectrum, which symbolises the presence of a particular species type that is in abundance [15]. Basically, Raman scattering in nanotubes results from the inelastic scattering of light from the nanotubes, leading to an increase or decrease in the energy of the incident light due to an emission or absorption of a phonon present in the nanotube.

\section{X-Ray diffraction (XRD)}

This technique is used to obtain some information on the interlayer spacing, the structural strain, the impurities, SWNT bundles, several layers of MWNTs and allows morphological information for an unlimited number of crystals[84]. In X-ray diffraction system, electrons emitted from the filament (cathode) are accelerated to target (anode) and X-rays characteristics of atoms in the irradiated area are emitted. By analysing their energy, the atoms can be identified and by counting emitted X-rays number, the atom concentration in the specimen can be determined. X-ray diffraction (XRD) is mostly used for bulk structure analysis. However, if the concentration of the active component is large enough, it can be appropriate for size determination. Quantitatively, a number average size is obtained from the equation below $[19,60]$.

$$
d=\frac{0.85 \lambda}{\left(B^{2}-b^{2}\right)^{1 / 2}=\cos \theta}
$$

Where, $b=$ value for a well-crystallized specimen, and $\lambda=$ wavelength.

\section{Thermal analysis (TGA/DTG)}

The thermal analysis involves a dynamic phenomenological approach to the study of materials by observing the response of these materials to a change in temperature. Thermal analysis methods are useful for identifying relative changes due to processing. It is used to study the degree of CNTs purification [84]. Thermal gravimetric analysis (TGA) and derivative thermal gravimetric (DTG) analysis methods controlled oxidation process 
that gives quantitative data on the weight fractions of carbon and metal catalyst in the sample, and the temperatures of bulk oxidation events [93].

\section{Elemental analysis}

The elemental analysis of raw-purified MWCNTs depicted carbon and hydrogen content in nanotubes. The purification of raw MWCNTs allowed the elimination of some catalyst impurities in oxidised form, and also raw MWCNTs could be functionalized with some oxygen-containing groups like- $\mathrm{COOH}$ groups and- $\mathrm{OH}$ groups that would be later confirmed by the elemental analysis [94].

\section{Absorption spectroscopy (UV, Vis and IR)}

Because of their unique electronic structure, CNTs and especially SWCNT have discrete optical absorptions that do not occur in other graphitic nanocarbon. Absorption Spectroscopic technique is very useful as a relative purity measurement of CNT. In the characterization of CNTs, IR spectroscopy is often used to determine impurities remaining from synthesis or molecules capped on the CNT surface. Numerous works are performed on organic molecules and CNTs: IR spectroscopy exhibits all the modification of the CNTs structure and reveals the nature of compounds added to the CNTs. The difference in catalytic activity performance between CNTs activated carbon and graphite samples in the oxidative dehydrogenation of ethylbenzene [14]. The highest catalytic activity is obtained with MWCNTs which are oxidised before the catalytic experiments. The possibilities of the use of CNTs for catalytic removal of $\mathrm{NOx}\left(\mathrm{NO}, \mathrm{NO}_{2}, \mathrm{NO}_{3}\right.$ ) were also investigated by FT-IR [95]. For a correct characterization of CNTs, all these techniques described herein cannot be used individually but must be used in complementary ways.

\section{Drug loading mechanism and cellular uptake of CNT's}

Nanotubes are hydrophobic in nature and do not show wetting behaviour for most aqueous solvents. It is reported that various organic solvents, $\mathrm{HNO}_{3}, \mathrm{~S}, \mathrm{Cs}, \mathrm{Rb}, \mathrm{Se}$, and various oxides such as $\mathrm{Bi}_{2} \mathrm{O}_{2}$ can wet nanotubes. Nanotube provides capillary pressure proportional to (1/D). Therefore, these wetting agents can be driven to fill inside the nanotube by the capillary pressure.

It is also likely to fill non-wetting agents inside a nanotube by applying a pressure which is higher than the capillary pressure. An effective alternative is to use wetting agents such as $\mathrm{HNO}_{3}$ to assist filling of non-wetting agents inside the nanotube [96] CNT's have very large surface area which allows multi-conjugation of various molecules on the sidewalls.

Molecules containing aromatic groups can be easily bound to CNTs non-covalently by strong $\pi-\pi$ interactions. Thus, CNTs possess unique and excellent structural, optical and electrical properties for the development of advanced drug delivery systems [19] (fig. 17).
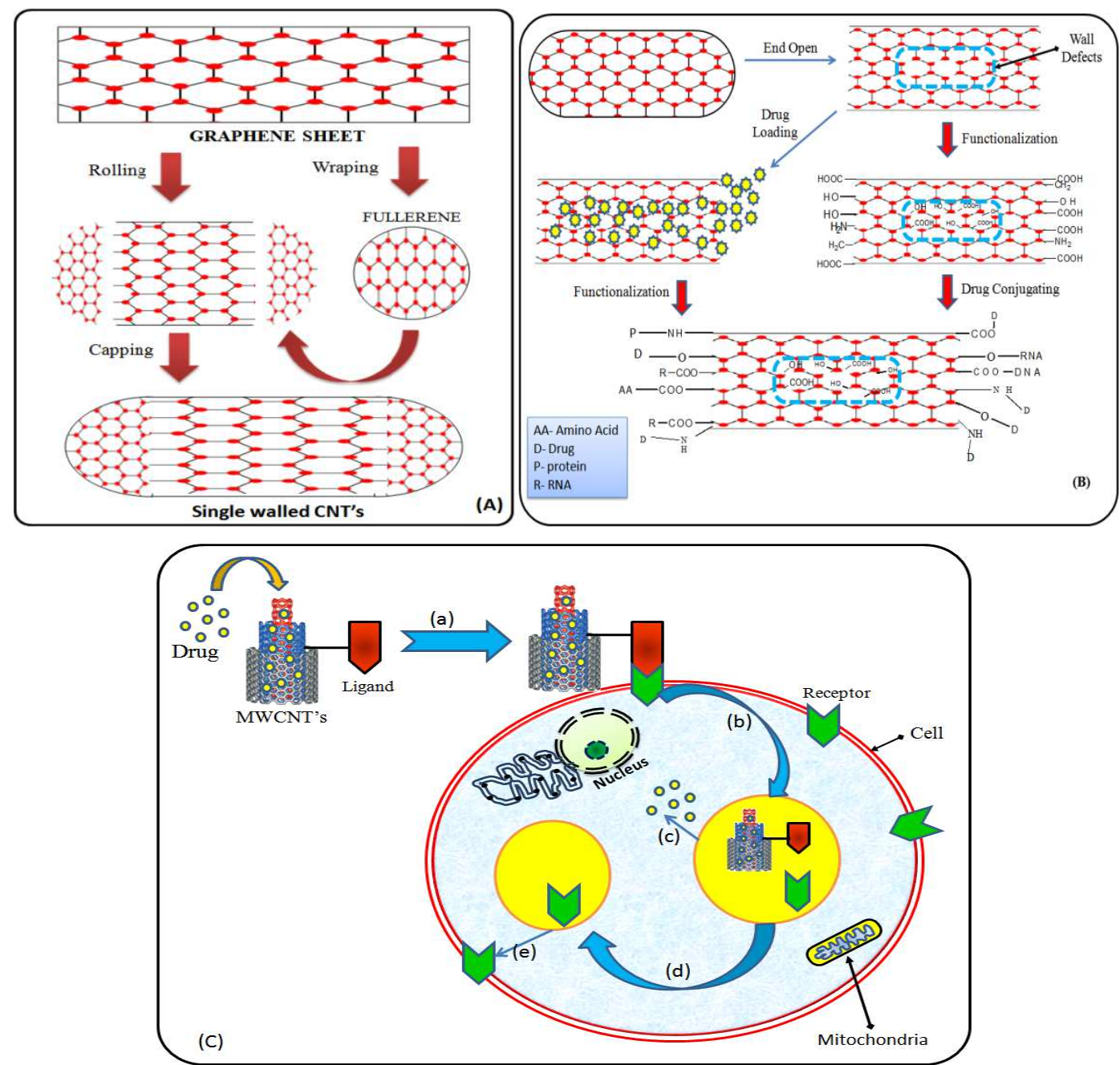

Fig. 17: Building of SWCNT's/MWCNT's and its physical and chemical treatment for use as drug carriers. (A) Demonstration of the structure formation of SWCNTs with the two ends closed. (B)The diagram of the strategy for the preparation of the CNT-based drug delivery systems. (C)Schematic representation of receptor-mediated endocytosis of CNTs. (a) Receptor association of ligand-conjugated drug-loaded CNTs, (b) endosomal uptake of conjugates, (c) release of drug at the targeted site, (d) formation of recycling vesicles and (e) receptor regeneration 


\section{Uptake OF CNT's BY cell}

CNTs have been aimed and actively explored as multipurpose, innovative nano-carriers for drug-delivery systems. Thanks to their very high aspect ratio, CNTs can penetrate the cell membrane and be uptaken by cells. After entering the cell, CNTs are mainly located inside cell endosomes and lysosomes. Individualised CNTs are able to travel through various cellular barriers and even enter the nucleus [97]. The applicable cell-internalization mechanisms for CNTs are:-Endocytosis-phagocytosis pathway. Endocytosis represents the engulfing of an extracellular particle by the cell (for example, viruses, $\sim 100 \mathrm{~nm}$ in size) through the formation of a vesicle that is then integrated into the cell. Endocytosis is an energyusing process in which cells absorb molecules (proteins) by engulfing them. Endocytosis is mediated by formation of vesicles, so called endosomes, containing cell bound materials that segregate from the plasma membrane and get internalised.

Passive diffusion-Phagocytosis is similar to endocytosis, but usually involves an uptake of larger particles, such as bacteria $(\sim 1 \mu \mathrm{m})$. In the passive diffusion pathway, CNTs cross the lipid bilayer in a needle-like manner $[98,99]$. The uptake mechanism of SWCNTs through phagocytosis can be enhanced by functionalization through conjugation with phospholipids. Raffa et al. reported the cellular uptake of nanotubes within lysosomes and phagosomes of healthy and normal cells [100].

These two processes are energy-dependent and are hindered at low temperatures (fig. 18) Energy-dependent endocytosis was reported as the main internalisation mechanism of SWCNT's bound to various types of proteins [101]. In addition, the imaging of SWCNT's within the phagosomes and lysosomes of healthy cells also suggests uptake by phagocytosis [102]. Uptake by diffusion was reported for MWCNT's [103]. Here, shorter (i.e., $<1 \mu \mathrm{m}$ ) MWCNT's were readily internalised by cells, while longer ones were not. Short CNTs can act as straight 'nano-needles', able to penetrate the cell membrane more efficiently than the longer CNTs, which are often arranged in a coiled or bundled shape, hindering their efficient uptake. Size, type, the chemistry of functionalization, charge and hydrophobic nature of nanotubes plays a major role in cellular uptake.[104] The f-CNTs having lengths around $100 \mathrm{~nm}$ are able to fit in Clathrin and caveolae vehicle, while CNTs with lengths more than $500 \mathrm{~nm}$ may probably be uptaken by the macropinocytosis process. Well, individualised MWCNTs with length around 300 to $400 \mathrm{~nm}$ can be easily cross the cell membrane and rapidly entered into the cells and freely traffic in cytoplasm within hr of post internalisation. The f-CNTs penetrate inside cells at $4{ }^{\circ} \mathrm{C}$. They may also penetrate into cells in presence of inhibitors of endocytosis i.e. sodium azide, 2, 4-dinitrophenol (DNP).

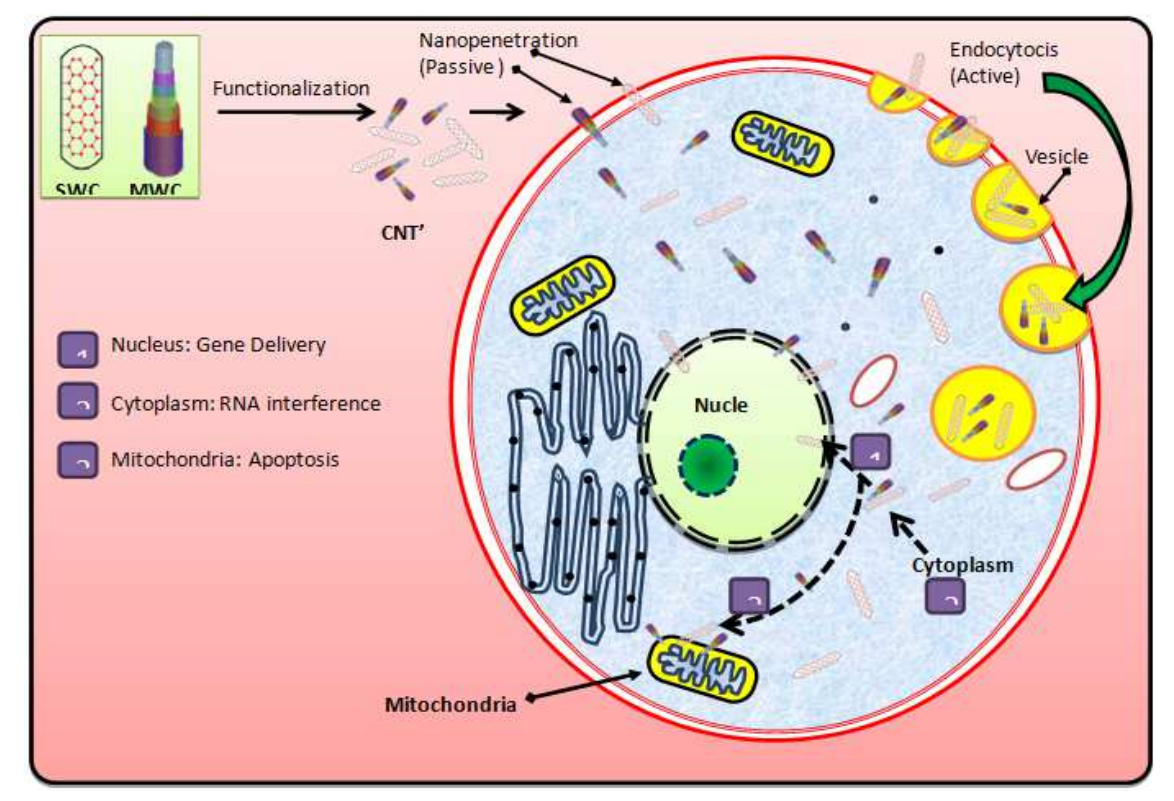

Fig. 18: Possible mechanisms of CNT and cell interactions showing receptor-mediated endocytosis or nano penetration, which is functionalization dependent

\section{Breakdown mechanism of cnts in the body}

A group of Swedish and American scientists has shown for the first time that carbon nanotubes can be broken down by alysosomal enzymeMyeloperoxidase (MPO)--an abundant enzyme of neutrophils granulocytes found in white blood cells and to a lesser extent also in certain macrophages [105]. Since, it clearly shows that endogenous MPO use to neutralise harmful bacteria and also found that the enzyme also works on carbon nanotubes, breaking them down into water and carbon dioxide.Shvedova et al., (2012) [106] reported that, in simple biochemical model systems, MPO turned out to be effective in oxidative biodegradation of SWCNT via a plethora of intermediate aliphatic and aromatic products to ultimately yield carbon dioxide $\left(\mathrm{CO}_{2}\right)$ and water $\left(\mathrm{H}_{2} \mathrm{O}\right)$ by a combination of two pathways associated with:

i) Hypochlorite generated by the enzyme in the presence of chloride, and

ii) Reactive intermediates of the enzyme [107].

The researchers also showed that carbon nanotubes that have been broken down by MPO no longer give rise to inflammation in mice [108].

\section{Toxicity OF CNT's}

In cases where CNTs have a toxic interaction by cells, the mechanisms of toxicity are coming into focus. Results suggest CNTs may cause harm to cells by activating many pathways at once, mostly involving DNA damage $[106,108]$. In one study, most cells incubated with CNTs halt at the G1 phase of the cell cycle [109]. Another study showed that mesothelial cells exposed to SWCNTs at concentrations $\sim 25 \mu \mathrm{g} / \mathrm{cm}^{2}$ activated DNA recovery along with changes in the cell cycle and generation of apoptotic signals. It was also observed that CNT/DNA interaction was the preferred route of toxicity in a 3-hour incubation study with $96 \mu \mathrm{g}$ SWCNT $/ \mathrm{cm}^{2}$, which induced DNA damage (through micronucleus generation) in lung fibroblasts [110]. It should be possible, through the observation of specific toxic events that result from incubations with different types of f-CNTs, to test for functional groups that reduce the severity of such events.

The harmful effect of nanoparticles arises because of high surface area and intrinsic toxicity of the surface [111]. CNT, in the context of toxicology, can be classified as 'nanoparticles' due to their nanoscale 
dimensions, therefore unexpected toxicological effects upon contact with biological systems may be induced.

The study of the adverse effects of nano-sized particles and fibres and their interaction in the living organism has been termed as "nanotoxicology". A nanosized particle could have the potential to cause the toxicity.

Certain properties determine the toxicity of nano-sized particles:

- The surface area/mass ratio of the particles; if the particle is having the larger surface area, it provides the greater contact with the cellular membrane, and as well as provides greater capacity for adsorption and transport of toxic substance.
- Retention of particles within a physiological environment; retention time determines the cellular contact and therefore causes the greater chances for damage. Retention time also determines its mobility either through clearance or migration to nearby tissue.

- Inherent toxicity of the contaminants present in nanomaterials.

The basic idea of nanomaterials' toxicity can be revealed by its lung deposition. The lung deposition of a nanosized material depends upon its surface area/mass ratio. $\mathrm{C}_{60}$ fullerenes do not prove significant toxicity, it shows the speedy distribution in rates and deposition in many tissues like brain, liver and spleen [112, 113]. Studies showed the toxicity profile of CNTs are summarised in (table 4).

Table 4: Toxicity of CNT's

\begin{tabular}{|c|c|c|c|c|}
\hline $\begin{array}{l}\text { S. } \\
\text { No. }\end{array}$ & CNTs description & $\begin{array}{l}\text { Mode of administration/exposure } \\
\text { condition }\end{array}$ & Toxicity/Comments & Ref \\
\hline \multicolumn{5}{|c|}{ Lung toxicity } \\
\hline 1 & $\begin{array}{l}\text { Unrefined CNT's } \\
\text { (Synthesised via Arc- } \\
\text { Discharge Sublimation } \\
\text { Method) }\end{array}$ & $\begin{array}{l}\text { Intrathecal installation (dispersion in } \\
\text { small amount of surfactants) }\end{array}$ & $\begin{array}{l}\text { No measurable pulmonary dysfunction (as seen by either non- } \\
\text { invasive procedure or BAL examination. } \\
\text { Comments- } \\
\text { Working with soot containing carbon nanotubes is unlikely to } \\
\text { be associated with any health risk. }\end{array}$ & {$[35]$} \\
\hline 2 & $\begin{array}{l}\text { MWCNTs (produced by } \\
\text { arc-discharge and CVD } \\
\text { methods) }\end{array}$ & $\begin{array}{l}\text { Intratracheal instillation (suspension } \\
\text { in sterile saline with SDS) }\end{array}$ & $\begin{array}{l}\text { A significant evidence of pulmonary toxicity. Alveolar } \\
\text { Macrophage infiltration in BAL of all non-control animals. } \\
\text { Multiple lesion was observed in CNT's exposed animals. } \\
\text { Comments- } \\
\text { Alveolar macrophage infiltration was absent in pyrograph } \\
\text { MWCNTs. Exposure time was critical for induction of } \\
\text { pathology. }\end{array}$ & [114] \\
\hline 4 & Pristine laser SWCNTs & $\begin{array}{l}\text { Intratracheal installation (in } \\
\text { phosphate buffer saline solution with } \\
1 \% \text { Tween } 80 \text { ) }\end{array}$ & $\begin{array}{l}15 \% \text { initial mortality was seen, the occurrence of only transient } \\
\text { inflammation of SWCNTs and non-dose dependent tissue } \\
\text { multimodal granulomas. } \\
\text { Comments- } \\
\text { Lung asphyxiation was attributed to the initial mortality. } \\
\text { Multimodal granuloma was considered inconsistent with the } \\
\text { lack of lung toxicity. }\end{array}$ & [115] \\
\hline \multicolumn{5}{|c|}{ 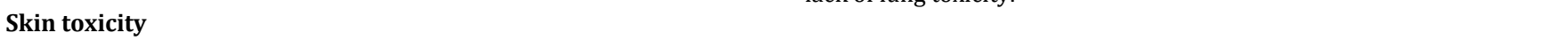 } \\
\hline 5 & $\begin{array}{l}\text { CNT's synthesised via } \\
\text { the arc discharge } \\
\text { process }\end{array}$ & $-\mathrm{h}$ & $\begin{array}{l}\text { No irritation in comparison to a CNT-free soot control } \\
\text { Comments- } \\
\text { 'No special precautions have to be taken while handling these } \\
\text { carbon nanostructures' }\end{array}$ & [116] \\
\hline \multicolumn{5}{|c|}{ Carvoni nanustructures } \\
\hline 6 & $\begin{array}{l}\text { Water dispersible } \\
\text { SWCNTs }\end{array}$ & $\begin{array}{l}\text { In human dermal fibroblast cell } \\
\text { cultures }\end{array}$ & $\begin{array}{l}\text { With an increase in the degree of sidewall functionalization, the } \\
\text { SWCNT's became less cytotoxic. } \\
\text { Cytotoxicity Low (on the basis of in vitro test) }\end{array}$ & [114] \\
\hline 7 & Pristine-laser SWNT & $\begin{array}{l}\text { Intratracheal instillation } \\
\text { (Suspension in PBS With 1\% Tween } \\
80\end{array}$ & $\begin{array}{l}\text { Exposure to the high dose produced mortality within } 24 \mathrm{~h} \text { post- } \\
\text { instillation. Pulmonary inflammation with non-dose-dependent } \\
\text { granulomas. } \\
\text { Comments- } \\
\text { Mechanical blockage of upper airways. Foreign tissue body } \\
\text { reaction. }\end{array}$ & [63] \\
\hline 8 & SWCNT cytotoxicity & $\begin{array}{l}\text { SWCNTs inhibited human embryonic } \\
\text { kidney (HEK 293) cells }\end{array}$ & $\begin{array}{l}\text { By inducing cell apoptosis and decreasing cellular-adhesion } \\
\text { ability. }\end{array}$ & \\
\hline 9 & $\begin{array}{l}\text { Utilising f-CNTs for } \\
\text { gene therapy }\end{array}$ & On the delivery of Plasmid DNA & $\begin{array}{l}\text { Low cytotoxicity and also suggested the use of the f-SWCNTs } \\
\text { for intracellular delivery using the mammalian HeLa cell. } \\
\text { Comments- } \\
\text { The ammonium functionalized-CNT's was bound to plasmid } \\
\text { DNA via electrostatic interaction and was internalised within } \\
\text { the mammalian cell. }\end{array}$ & [116] \\
\hline 10 & MWNT & $\begin{array}{l}\text { Intratracheal instillation } \\
\text { (Suspension in sterile } \\
0.9 \% \text { saline with } 1 \% \\
\text { Tween } 80 \text { ) }\end{array}$ & $\begin{array}{l}\text { Not ground MWNT accumulate in the airways, ground MWNT } \\
\text { were cleared more rapidly. Both MWNT have induced } \\
\text { inflammation (more marked for ground MWNT) and fibrotic } \\
\text { reactions. Also, both have caused pulmonary lesions at } 2 \text { mo. } \\
\text { Comments- } \\
\text { Length appears to modulate clearance kinetics. Biopersistence, } \\
\text { intrinsically toxic to the lung. }\end{array}$ & [117] \\
\hline 11 & Carboxylated CNT's & Intraperitoneal administration & $\begin{array}{l}\text { CNT accumulation in bone. } \\
\text { Comments- } \\
\text { Organ-specific accumulation of I. V. Administered nanotubes } \\
\text { could be visualised. No signs of renal or other severe acute } \\
\text { toxicity responses were observed. }\end{array}$ & [118] \\
\hline
\end{tabular}




\section{Applications of CNT's}

\section{Treatment of central nervous system disorders}

Central nervous system (CNS) disorders consist of neurodegenerative diseases and brain tumours. It is more difficult to diagnose and treat CNS disorders than any other diseases because of the unique and complex environment and the restricted anatomical access (blood brain barrier) of the CNS. Nanotechnology is promising to modernise the status quo in this field. Because of their tiny dimensions and accessible external or exterior modifications, nanomaterials are able to cross the blood-brain barrier by various targeting mechanisms and, thus, they can act as effective delivery carriers for targeting the brain. Both pristine and chemically functionalized CNTs have positive effects on neuronal growth, charge on the nanotubes could be manipulated to control neurite outgrowth [119], and CNTs functionalized with nerve growth factor or brain-derived neurotrophic factor could stimulate growth of neurons on the nanotube scaffold [120] proved that conventional tungsten and stainless steel wire electrodes coated with CNTs could enhance both recording and electrical stimulation of neurons in culture, rats and monkeys. CNT-coated electrodes are expected to improve current electrophysiological techniques and to promote the development of long-lasting brain-machine interfacing devices, both of which will aid the diagnosis and treatment of CNS disorders. The nanoparticle-based formulations of some chemotherapeutic agents (e. g. doxorubicin $[121,122]$ have the potential for the systemic chemotherapy of brain tumours with higher efficacy than the free agents. MWCNTs (p-MWCNTs or MWCNTs functionalized with DNA and siRNA) were found to be internalised by brain microglia (macrophage derived from migratory monocytes in the brain that are believed to be an effective target for brain cancer treatment) in vitro and in vivo without inducing proliferative and cytokine changes [123]. It indicated that MWCNTs may possibly act as a safe nanovector delivery system for immune therapies of brain cancers (e. g. gliomas) [124, 125].

\section{CNT'S in delivery of bioactive}

Bioactives are chemicals or chemical molecules that have some biological effect on our bodies. For example,Hydroxyapatite is a form of calcium phosphate having chemical resemblance with the mineral component of bones and teeth tissues. Tissue adhesion and bone growth get promoted and formed bone-like apatite layer which is biologically active. Thus, Hydroxyapatite classified as biocompatible and bioactive materials having biological applications, such as skeletal implants or dental and bone repair scaffolds[126] Amphotericin B-loaded MWCNT employed as efficient nano-carrier for antileishmanial therapy[127], Gemcitabine-loaded smart CNTs for effective targeting to the cancer cell. Materials containing CNTs may, however, be strong enough to build space elevators, spacecraft, artificial muscles, sea and land vehicles. SWCNTs can conduct twice the electricity of copper, making these materials excellent electrical conductors, and may also be used to improve rechargeable batteries and fuel cell production, for instance. CNT's also have a distinctive electron-transport property and commonly in a manufactured material bulk sample $30 \%$ of the SWCNTs are conductors and $70 \%$ are semiconductors [128].

\section{CNT's in cancer therapies}

Cancer is a disease characterised by out-of-control cell growth Cancer harms the body when damaged cells divide uncontrollably to form lumps or masses of tissue called tumours. CNTs are hopeful drug carriers in the target drug delivery systems for cancer therapies.

Table 5: Potential applications of CNT's; in vitro and in vivo evaluation

\begin{tabular}{|c|c|c|c|c|c|}
\hline $\begin{array}{l}\text { Functionalized } \\
\text { CNT's }\end{array}$ & Cell lines & Bioactives & Evaluation parameters & Outcomes of the study & Ref \\
\hline $\begin{array}{l}\text { PL-PEG-FA and PL- } \\
\text { PEG-FITC-SWCNT's. }\end{array}$ & Hela cells. & $\begin{array}{l}\text { Cy3-labeled } \\
\text { DNA }\end{array}$ & $\begin{array}{l}\text { - Atomic force } \\
\text { microscopy. } \\
\text { - Confocal laser scanning } \\
\text { microscopy. }\end{array}$ & $\begin{array}{l}\text { SWCNTS internalised in living cells can act } \\
\text { as tiny NIR "heaters" or "antennas". }\end{array}$ & {$[131]$} \\
\hline PL-PEG-SWCNT's & $\begin{array}{l}\text { CXCR4 cell- } \\
\text { surface receptors } \\
\text { in human } \\
\text { T cells and } \\
\text { PBMC cells }\end{array}$ & siRNA & $\begin{array}{l}\text { - Proliferation and } \\
\text { Cytotoxicity assay. } \\
\text { - Fluorescence analysis }\end{array}$ & $\begin{array}{l}\text { SWNTS can be used as molecular } \\
\text { transporters for human T cells and primary } \\
\text { cells, with superior silencing effects over } \\
\text { conventional liposome-based non-viral } \\
\text { agents. }\end{array}$ & [132] \\
\hline $\begin{array}{l}\text { MWCNT's-g-PCA } \\
\text { and MWCNT's-g- } \\
\text { PCA-PTX }\end{array}$ & $\begin{array}{l}\text { A549 and SKOV3 } \\
\text { cell lines }\end{array}$ & Paclitaxel & $\begin{array}{l}\text { - Cell line studies } \\
\text { - Electron microscopy } \\
\text { - Atomic force microscopy }\end{array}$ & $\begin{array}{l}\text { Conjugation of paclitaxel to MWNT- } g \text {-PCA is } \\
\text { an effective delivery system for cancer } \\
\text { chemotherapy. }\end{array}$ & [133] \\
\hline $\begin{array}{l}\text { Carboxylated } \\
\text { MWCNT's } \\
\text { (C-MWCNT's). }\end{array}$ & -- & $\begin{array}{l}\text { Epirubicin } \mathrm{HCl} \\
\text { via } \pi-\pi \text { stacking. }\end{array}$ & $\begin{array}{l}\text { - Adsorption efficiency } \\
\text { - In vitro release }\end{array}$ & $\begin{array}{l}\text { The amount of EPI released from the C- } \\
\text { MWCNT was } 30.65 \% \text { after } 6 \mathrm{~h} \text { in the acidic } \\
\text { solution, which is almost } 1.5 \text { times larger } \\
\text { than that in the neutral solution. }\end{array}$ & [134] \\
\hline $\begin{array}{l}\text { DOX-SWCNT-CHI- } \\
\text { FA and DOX- } \\
\text { SWCNT }\end{array}$ & $\begin{array}{l}\text { In vitro release } \\
\text { studies }\end{array}$ & Doxorubicin & $\begin{array}{l}\text { - Electron microscopy } \\
\text { - FTIR spectroscopy }\end{array}$ & $\begin{array}{l}\text { High drug loading capacity } \sim 91 \% \text { and } \\
\text { showed in controlled and sustained release } \\
\text { pattern of the developed formulations }\end{array}$ & [135] \\
\hline $\begin{array}{l}\text { Amb/Mannose- } \\
\text { MWCNT's }\end{array}$ & J774 cells & $\begin{array}{l}\text { Amphotericin B } \\
(A m b)\end{array}$ & $\begin{array}{l}\text { - CLSM } \\
\text { - In vitro and in vivo } \\
\text { studies. } \\
\text { - Macrophage uptake } \\
\text { study. }\end{array}$ & $\begin{array}{l}\text { Amb tubes showed better targeting } \\
\text { efficiency to macrophages i.e. J } 774 \text { cell } \\
\text { lines with reduced toxic effects associated } \\
\text { with Amb. }\end{array}$ & [136] \\
\hline $\begin{array}{l}\text { DOX/FA/CHI/ } \\
\text { SWNT'S }\end{array}$ & $\begin{array}{l}\text { SMMC-772 } \\
\text { Hepatocellular } \\
\text { carcinoma }\end{array}$ & Doxorubicin & $\begin{array}{l}\text { - Microplate reader } \\
\text { (Model } 680, \text { Bio-Rad) } \\
\text { - In vitro cell culture study } \\
\text { - In vivo studies } \\
\text { - Light microscopy }\end{array}$ & $\begin{array}{l}\text { The therapeutic efficiency of } \\
\text { DOX/FA/CHI/SWNT's was time-dependent } \\
\text { and dosage-dependent. } \\
\text { Tumour volumes reduced. }\end{array}$ & [137] \\
\hline $\begin{array}{l}\text { Biotin-SWNT's or } \\
\text { MWNT's }\end{array}$ & $\begin{array}{l}\text { Hela cells and } \\
\text { MCF-7 cancer cell } \\
\text { lines }\end{array}$ & Paclitaxel & - Flow cytometry & $\begin{array}{l}\text { Formation of a stable microtubule-taxoid } \\
\text { complex and finally caused apoptosis and } \\
\text { cell death }\end{array}$ & [138] \\
\hline $\begin{array}{l}\text { PAMAM } \\
\text { dendrimersFA- } \\
\text { treated MWNT's }\end{array}$ & Hela cell & Doxorubicin & $\begin{array}{l}\text { - Flow cytometry } \\
\text { - Confocal microscopy }\end{array}$ & $\begin{array}{l}\text { Targeting of FA receptors overexpress } \\
\text { cancer cells }\end{array}$ & [139] \\
\hline $\begin{array}{l}\text { SWCNT's } \\
\text { Polysaccharide } \\
\text { [sodium alginate } \\
\text { (ALG) and Chitosan } \\
\text { (CHI)] }\end{array}$ & Hela cells & Doxorubicin & - Magnetic field & $\begin{array}{l}\text { Modified CNTS reduced side-effects as well } \\
\text { as increase therapeutic amount of the drug } \\
\text { in patient }\end{array}$ & [139] \\
\hline
\end{tabular}


In vivo biodistribution and highly efficient tumour targeting of carbon nanotubes in mice for cancer therapy [77]. Tumor-targeted drug delivery system is also possible via covalent conjugation of the specific ligand to oxidised SWCNT. Studies performed in vitro demonstrated a rapid decrease of tumour size in comparison to nontargeted SWCNT thus ensuring maximum drug efficiency with minimum side effects $[10,129]$. The potential application of CNT's in drug delivery has been compiled in table 5 with special reference to in vitro and in vivo evaluation.

Many functionalized carbon nanotubes may determine useful applications in the area of materials science and technology, including photovoltaics. Also in medicinal chemistry carbon nanotubes are set to act an important role. They utilise as drug delivery scaffolds and substrates for vaccines. CNT functionalized through bioactive moieties are particularly fitted for targeted drug delivery. In fact, not only they get less toxic but also display a high tendency to cross cell membranes [130]. Some of the examples of active moieties are doxorubicin-loaded SWNTs, paclitaxel-CNT[28], dexamethasone mesylate-loaded MWCNTs [62]. Molecular and ionic migration takes place by carbon nanotubes, thus offering novel opportunities designed for molecular sensors and electronic nucleic acid sequencing. The variation of a carbon nanotube on a molecular level via biological molecules is effectively an example of the 'bottom-up' fabrication principle of bio-nanotechnology.

\section{Medical applications}

CNT's bound to an antibody, which is developed by chickens, have been shown to be useful in laboratory tests to demolish breast cancer tumours. The antibody containing nanotubes is attracted to proteins produced by one type of breast cancer cell. Then the nanotubes absorb light from an infrared laser, incinerating the nanotube and attached to the tumour. Using nanotubes as a cellular scale needle to convey quantum dots and proteins in cancer cellsImprove the healing process for broken bones by putting up a carbon nanotube scaffold for new bone material to grow on [140].

An additional application of CNT's in medicine is for sensing the molecules or species. Many studies on the electrochemical reactivity of carbon nanotubes showed that carbon nanotubes can enhance the biomolecules and promote the transfer of electron in proteins (heam containing proteins). In heam containing proteins, carbon nanotubes are able to access the heamcenter of biomolecules that is generally not sensed by the glass electrodes. CNT's can also be utilised as blood vessels in order to deliver drugs to their target. When the drug delivery is done that way, the drug dosage can be lowered (and it's cheaper for the pharmaceutical companies). There are two methods, both equally effective-

a) The drug can be attached to the side or behind, or

b) The drug can actually be placed inside the nanotube.

Synthetic muscles-due to their high contraction/extension ratio given an electric current CNT'sare ideal for synthetic muscle.

Artificial muscles-CNT's have enough contractility to make them candidates to replace muscle tissue [14].

Nanotubes function like a needle at the cellular level. This property is used in attaching molecules that are attracted to cancer cells to nanotubes to deliver drugs directly to diseased cells. The attachment of ethylene glycol molecules to nanoparticles of nanotubes stops WBCs from recognising the nanoparticles as foreign materials, allowing them to circulate in the blood streams long enough to attach in cancer tumour therapy. Magnetic fields drive drug-loaded nanoparticles to reduce blood vessel blockages in an animal study. Functionalized CNT's used as emerging nano vectors for the delivery of therapeutics. Functionalization of SWCNT's enhances solubility and allow for efficient tumor-targeting drug delivery. It prevents SWCNT's from being cytotoxic and altering the function of immune cells [141].

\section{CONCLUSION}

CNTs are discussed and described in this review from their discovery to present day in the requisites of historical background, structure, properties, growth mechanism, synthesis, purification, characterization methods, cellular uptake of CNT's, breakdown mechanism, toxicity and its biomedical applications. Carbon nanotubes may have only recently caught the attention of the world but many modernizations have been made since their discovery. They are unique nanostructures that display the desirable properties of any other known material. Production methods include many approaches which change types, yields, and structural surfaces of CNTs, which results in the change in the electrical and mechanical properties, and the actual structure of CNTs. Useful techniques for CNTs characterization are used are Electron Microscope, XRD etc. But the most powerful technique to characterise CNT's remains the Raman spectroscopy in which without sample preparation, a fast and nondestructive analysis is possible. Significant advances have been made in the delivery of anticancer and anti-inflammatory drugs, and bioactive molecules i.e. DNA, RNA and proteins. Drugs and biomolecules can be loaded in CNTs, which can then be utilised as targeted molecules. The toxicity of pristine CNT's is still a major concern based on the highly conflicting results obtained by various researchers. However, functionalized CNTs have been considered biocompatible and safe for drug and biomolecule delivery applications as they are soluble in physiological media and nontoxic. They have shown no accumulation in the tissues; conversely, once functionalized, they can be readily excreted through the renal route by means of degradation through myeloperoxidase (MOP) enzyme. However, CNT-based delivery systems are undoubtedly very promising in terms of their numerous advantages over the existing technologies.

\section{CONFLICT OF INTERESTS}

Authors hereby declare that there are no conflicts

\section{REFERENCES}

1. Moghimi SM, Hunter AC, Murray JC. Long-circulating and target-specific nanoparticles: theory to practice. Pharmacol Rev 2001;53:283-318.

2. Hamidi M, Azadi A, Rafiei P. Hydrogel nanoparticles in drug delivery. Adv Drug Delivery Rev 2008;60:1638-49.

3. Pradeep T. Nano: the essentials: Understanding Nanoscience and Nanotechnology; 2007.

4. Iijima S. Helical microtubules of graphitic carbon. Nature; 1991. p. $56-8$.

5. Davis JJ, Coleman KS, Azamian BR, Bagshaw CB, Green ML. Chemical and biochemical sensing with modified single walled carbon nanotubes. Chem Eur J 2003;9:3732-9.

6. Kroto HW, Heath JR, O'Brien SC, Curl RF, Smalley RE. C60: buckminsterfullerene. Nature 1985;318:162-3.

7. Krätschmer W, Lamb LD, Fostiropoulos K, Huffman DR. C60:a new form of carbon. Nature 1990;347:354-8.

8. Galindo-Rodríguez SA, Puel F, Briançon S, Allémann E, Doelker E, Fessi H. Comparative scale-up of three methods for producing ibuprofen-loaded nanoparticles. Eur J Pharm Sci 2005;25:357-67.

9. Bethune D, Klang C, De Vries M, Gorman G, Savoy R, Vazquez J, et al. Cobalt-catalysed growth of carbon nanotubes with singleatomic-layer walls. Lett Nat 1993;365:605-7.

10. Andersen AJ, Wibroe PP, Moghimi SM. Perspectives on carbon nanotube-mediated adverse immune effects. Adv Drug Delivery Rev 2012;64:1700-5.

11. Sundaramoorthy R, Vuyyuru M, Dhanaraju MD. Carbon nanotube: a flexible approach for nanomedicine and drug delivery. Asian J Pharm Clin Res 2015;8:7.

12. Martin CR, Kohli P. The emerging field of nanotube biotechnology. Nat Rev Drug Discovery 2003;2:29-37.

13. Moloni K, Lal A, Lagally MG. Sharpened carbon nanotube probes. International Symposium on Optical Science and Technology: International Society for Optics and Photonics; 2000. p. 76-83.

14. Singh GB, Baburao C, Pispati V, Pathipati H, Muthy N, Prassana S, et al. Carbon nanotubes-a novel drug delivery system; 2012. 
15. Aqel A, El-Nour KM, Ammar RA, Al-Warthan A. Carbon nanotubes, science and technology part (I) structure, synthesis and characterisation. Arabian J Chem 2012;5:1-23.

16. Baughman RH, Zakhidov AA, de Heer WA. Carbon nanotubes-the route toward applications. Science 2002;297:787-92.

17. Qu L, Dai L. Substrate-enhanced electroless deposition of metal nanoparticles on carbon nanotubes. J Am Chem Soc 2005;127:10806-7.

18. Britto P, Santhanam K, Ajayan P. Carbon nanotube electrode for oxidation of dopamine. Bioelectrochem Bioenerg 1996;41:1215 .

19. Meyyappan M. Carbon nanotubes: science and applications: CRC Press; 2005.

20. Kong J, Chapline MG, Dai H. Functionalized carbon nanotubes for molecular hydrogen sensors. Adv Materials 2001;13:13846

21. Mehra NK, Palakurthi S. Interactions between carbon nanotubes and bioactives: a drug delivery perspective. Drug Discovery Today 2016;21:585-97.

22. Sajid MI, Jamshaid U, Jamshaid T, Zafar N, Fessi H, Elaissari A. Carbon nanotubes from synthesis to in vivo biomedical applications. Int J Pharm 2016;501:278-99.

23. Miao M. Yarn spun from carbon nanotube forests: production, structure, properties and applications. Particuology 2013;11:378-93.

24. Hamers B, ST PJ, Veld M. The Wondrous World of Carbon Nanotubes; 2003.

25. Zhang R, Zhang Y, Wei F. Chapter 4-synthesis and properties of ultralong carbon nanotubes. In: Mark JS, Vesselin NS, Zhangzhang YinA2-Mark J Schulz VNS, Zhangzhang Y. editors. Nanotube Superfiber Materials. Boston: William Andrew Publishing; 2014. p. 87-136.

26. Rinzler A, Liu J, Dai H, Nikolaev P, Huffman C, Rodriguez-Macias $\mathrm{F}$, et al. Large-scale purification of single-wall carbon nanotubes: process, product, and characterization. Appl Phys A: Mater Sci Process 1998;67:29-37.

27. Thess A, Lee R, Nikolaev P, Dai H, Petit P, Robert J, et al. Crystalline ropes of metallic carbon nanotubes. Sci AAASWeekly Paper Edition 1996;273:483-7.

28. Singh P, Tripathi R, Saxena A. Synthesis of carbon nanotubes and their biomedical application. J Optoelectronics Biomed Mater 2010;2:91-8.

29. Dai H. Carbon nanotubes: opportunities and challenges. Surface Sci 2002;500:218-41.

30. Hata K, Futaba DN, Mizuno K, Namai T, Yumura M, Iijima S. Water-assisted highly efficient synthesis of impurity-free single-walled carbon nanotubes. Science 2004;306:1362-4.

31. Kong J, Soh HT, Cassell AM, Quate CF, Dai H. Synthesis of individual single-walled carbon nanotubes on patterned silicon wafers. Nature 1998;395:878-81.

32. Lacerda L, Bianco A, Prato M, Kostarelos K. Carbon nanotubes as nanomedicines: from toxicology to pharmacology. Adv Drug Delivery Rev 2006;58:1460-70.

33. Ebbesen T, Ajayan P. Large-scale synthesis of carbon nanotubes. Nature 1992;358:220-2.

34. Jung SH, Kim MR, Jeong SH, Kim SU, Lee OJ, Lee KH, et al. Highyield synthesis of multi-walled carbon nanotubes by arc discharge in liquid nitrogen. Appl Phys A: Solids Surf 2003;76:285-6.

35. Daenen M, De Fouw R, Hamers B, Janssen P, Schouteden K, Veld M. The Wondrous World of Carbon Nanotubes. A Review of Current Carbon Nanotube Technologies. Eindhoven university of technology; 2003. p. 89.

36. Mehra NK, Palakurthi S. Interactions between carbon nanotubes and bio actives: a drug delivery perspective. Drug Discovery Today 2016;21:585-97.

37. Zhao B, Hu H, Niyogi S, Itkis ME, Hamon MA, Bhowmik P, et al. Chromatographic purification and properties of soluble singlewalled carbon nanotubes. J Am Chem Soc 2001;123:11673-7.

38. Mehra NKJ AK, Lodhi N Raj RD V, Mishra D, Nahar M, Jain NK. Challenges in the use of carbon nanotubes for biomedical applic ations. Ther Drug Carrier Syst 2008;25:169-207.

39. Hou PX, Liu C, Cheng HM. Purification of carbon nanotubes. Carbon 2008;46:2003-25.
40. Tsang S, Harris P, Green M. Thinning and the opening of carbon nanotubes by oxidation using carbon dioxide. Nature London 1993;362:520.

41. Hiura H, Ebbesen TW, Tanigaki K. Opening and purification of carbon nanotubes in high yields. Adv Mater 1995;7:275-6.

42. Ikazaki F, Ohshima S, Uchida K, Kuriki Y, Hayakawa H, Yumura $\mathrm{M}$, et al. Chemical purification of carbon nanotubes by use of graphite intercalation compounds. Carbon 1994;32:1539-41.

43. Ju-Nam Y, Lead JR. Manufactured nanoparticles: an overview of their chemistry, interactions and potential environmental implications. Sci Total Environment 2008;400:396-414.

44. Sinha N, Yeow JW. Carbon nanotubes for biomedical applications. Nano-Bioscience, IEEE Transactions 2005;4:18095.

45. Goto H, Furuta T, Tokune T, Fujiwara Y, Ohashi T. Method of manufacturing carbon nanotube. US Patent 20,020,090,468; 2002.

46. Chiang I, Brinson B, Smalley R, Margrave J, Hauge R. Purification and Characterization of single-wall carbon nanotubes. J Physical Chem B 2001;105:1157-61.

47. Harutyunyan AR, Pradhan BK, Chang J, Chen G, Eklund PC. Purification of single-wall carbon nanotubes by selective microwave heating of catalyst particles. J Phys Chem B 2002;106:8671-5.

48. Farkas E, Elizabeth Anderson M, Chen Z, Rinzler AG. Length sorting $<\mathrm{i}>$ cut $</ \mathrm{i}>$ single wall carbon nanotubes by high performance liquid chromatography. Chem Phys Lett 2002;363:111-6.

49. Hou P, Liu C, Tong $\mathrm{Y}, \mathrm{Xu} \mathrm{S}$, Liu M, Cheng H. Purification of single-walled carbon nanotubes synthesized by the hydrogen arc-discharge method. J Mater Res Pittsburgh 2001;16:2526-9.

50. Kajiura H, Tsutsui S, Huang H, Murakami Y. High-quality singlewalled carbon nanotubes from arc-produced soot. Chem Phys Lett 2002;364:586-92.

51. Moon JM, An KH, Lee YH, Park YS, Bae DJ, Park GS. The highyield purification process of singlewalled carbon nanotubes. J Physical Chem B 2001;105:5677-81.

52. Huang H, Shiraishi M, Yamada A, Kajiura H, Ata M. Ultrasonic reflux system for one-step purification of carbon nanostructures. Google Patents; 2001.

53. Borowiak-Palen E, Pichler T, Liu X, Knupfer M, Graff A, Jost O, et al. Reduced diameter distribution of single-wall carbon nanotubes by selective oxidation. Chem Phys Lett 2002;363:567-72.

54. Bandow S, Rao A, Williams K, Thess A, Smalley R, Eklund P. Purification of single-wall carbon nanotubes by microfiltration. J Physical Chem B 1997;101:8839-42.

55. Georgakilas V, Voulgaris D, Vazquez E, Prato M, Guldi DM, Kukovecz A, et al. Purification of HiPCO carbon nanotubes via organic functionalization. J Am Chem Soc 2002;124:14318-9.

56. Nepal D, Kim DS, Geckeler KE. A facile and rapid purification method for single-walled carbon nanotubes. Carbon 2005;43:660-2.

57. Shelimov KB, Esenaliev RO, Rinzler AG, Huffman CB, Smalley RE. Purification of single-wall carbon nanotubes by ultrasonically assisted filtration. Chem Physics Lett 1998;282:429-34.

58. Gao B, Bower C, Lorentzen J, Fleming L, Kleinhammes A, Tang X, et al. Enhanced saturation lithium composition in ball-milled singlewalled carbon nanotubes. Chem Phys Lett 2000;327:69-75.

59. Thiên-Nga L, Hernadi K, Ljubovic E, Garaj S, Forró L. Mechanical purification of single-walled carbon nanotube bundles from catalytic particles. Nano Lett 2002;2:1349-52.

60. Aqel A, El-Nour KMMA, Ammar RAA, Al-Warthan A. Carbon nanotubes, science and technology part (I) structure, synthesis and characterisation. Arabian J Chem 2012;5:1-23.

61. Niyogi S, Hu H, Hamon M, Bhowmik P, Zhao B, Rozenzhak S, et al. Chromatographic purification of soluble single-walled carbon nanotubes (s-SWNTS). J Am Chem Soc 2001;123:733.

62. Peretz S, Regev O. Carbon nanotubes as nanocarriers in medicine. Curr Opin Colloid Interface Sci 2012;17:360-8.

63. Sayes CM, Liang F, Hudson JL, Mendez J, Guo W, Beach JM, et al. Functionalization density dependence of single-walled carbon nanotubes cytotoxicity in vitro. Toxicol Lett 2006;161:135-42. 
64. Wang Y, Iqbal Z, Malhotra SV. Functionalization of carbon nanotubes with amines and enzymes. Chem Phys Lett 2005;402:96-101.

65. Shim M, Shi Kam NW, Chen RJ, Li Y, Dai H. Functionalization of carbon nanotubes for biocompatibility and biomolecular recognition. Nano Lett 2002;2:285-8.

66. Qin Y, Liu L, Shi J, Wu W, Zhang J, Guo ZX, et al. Large-scale preparation of solubilized carbon nanotubes. Chem Mater 2003; $15: 3256-60$

67. Kirikova M, Ivanov A, Savilov S, Lunin V. Modification of multiwalled carbon nanotubes by carboxy groups and determination of the degree of functionalization. Russ Chem Bull 2008;57:298-303.

68. Campidelli S, Klumpp C, Bianco A, Guldi DM, Prato M. Functionalization of CNT: synthesis and applications in photovoltaics and biology. J Phys Org Chem 2006;19:531-9.

69. Hirsch A, Vostrowsky 0. Functionalization of carbon nanotubes. Functional molecular nanostructures: Springer; 2005. p. 193-237.

70. Rey DA, Batt CA, Miller JC. Carbon nanotubes in biomedical applications. Nanotechnol Law Business 2006;3:263.

71. Hirsch A. Functionalization of single-walled carbon nanotubes. Angew Chem Int Ed 2002;41:1853-9.

72. Liu J, Rinzler AG, Dai H, Hafner JH, Bradley RK, Boul PJ, et al. Fullerene pipes. Science 1998;280:1253-6.

73. Banerjee S, Wong SS. Rational sidewall functionalization and purification of single-walled carbon nanotubes by solutionphase ozonolysis. J Physical Chem B 2002;106:12144-51.

74. Itkis $M$, Niyogi $S$, Meng $M$, Hamon $M, H u H$, Haddon $R$. Spectroscopic study of the fermi level electronic structure of single-walled carbon nanotubes. Nano Lett 2002;2:155-9.

75. Hirsch A. Functionalization of single-walled carbon nanotubes. Angew Chem 2002;41:1853-9.

76. Kahn MG, Banerjee S, Wong SS. Solubilization of oxidized single-walled carbon nanotubes in organic and aqueous solvents through organic derivatization. Nano Lett 2002;2:1215-8.

77. Kesharwani P, Ghanghoria R, Jain NK. Carbon nanotube exploration in cancer cell lines. Drug Discovery Today 2012;17:1023-30

78. Bottini M, Rosato N, Bottini N. PEG-modified carbon nanotubes in biomedicine: current status and challenges ahead Biomacromolecules 2011;12:3381-93.

79. Liu Z, Tabakman S, Welsher K, Dai H. Carbon nanotubes in biology and medicine: in vitro and in vivo detection, imaging and drug delivery. Nano Res 2009;2:85-120.

80. Lin Y, Taylor S, Li H, Fernando KS, Qu L, Wang W, et al. Advances toward bioapplications of carbon nanotubes. J Mater Chem 2004;14:527-41.

81. Seminoff LA, Gleeson JM, Zheng J, Olsen GB, Holmberg D, Mohammad SF, et al. A self-regulating insulin delivery system. II. In vivo characteristics of a synthetic glycosylated insulin. Int J Pharm 1989;54:251-7.

82. Li GD, Tang ZK, Wang N, Chen JS. Structural study of the 0.4-nm single-walled carbon nanotubes aligned in channels of AlP04-5 crystal. Carbon 2002;40:917-21.

83. Liu B, Jiang H, Johnson HT, Huang Y. The influence of mechanical deformation on the electrical properties of single wall carbon nanotubes. J Mechanics Physics Solids 2004;52:1-26.

84. Atike İ. Growth and characterization of carbon nanotubes over Co-Mo/MgO catalysts; 2010.

85. Andrews R, Jacques D, Qian D, Dickey EC. Purification and structural annealing of multiwalled carbon nanotubes at graphitization temperatures. Carbon 2001;39:1681-7.

86. Liao X, Serquis A, Jia Q, Peterson D, Zhu Y, Xu H. Effect of catalyst composition on carbon nanotube growth. Appl Phys Lett 2003;82:2694-6.

87. Cowley J, Nikolaev P, Thess A, Smalley RE. Electron nanodiffraction study of carbon single-walled nanotube ropes. Chem Phys Lett 1997;265:379-84.

88. Terrones M, Terrones H, Grobert N, Hsu W, Zhu Y, Hare J, et al. Efficient route to large arrays of $<$ equation $><$ font face $=$ 'verdana' $>$ CN $</$ font $><$ sub $>$ x $</$ sub $><$ /equation $>$ nanofibe rs by pyrolysis of ferrocene/melamine mixtures. Appl Phys Lett 1999;75:3932-4.
89. Hafner J, Cheung CL, Woolley A, Lieber C. Structural and functional imaging with carbon nanotube AFM probes. Prog Biophys Mol Biol 2001;77:73-110.

90. Kong J, Zhou C, Morpurgo A, Soh H, Quate C, Marcus C, et al. Synthesis, integration, and electrical properties of individual single-walled carbon nanotubes. Appl Phys A 1999;69:305-8.

91. Dresselhaus M, Dresselhaus G. For a review, see. Adv Phys 1981;30:139.

92. Brar V, Samsonidze GG, Dresselhaus M, Dresselhaus G, Saito R Swan A, et al. Second-order harmonic and combination modes in graphite, single-wall carbon nanotube bundles, and isolated single-wall carbon nanotubes. Phys Rev B 2002;66:1-11.

93. Arepalli S, Nikolaev P, Gorelik O, Hadjiev VG, Holmes W, Files B, et al. Protocol for the characterization of single-wall carbon nanotube material quality. Carbon 2004;42:1783-91.

94. Guggenheim S, Van Groos AK. Baseline studies of the clay minerals society source clays: thermal analysis. Clays Clay Minerals 2001;49:433-43.

95. Jain AK, Dubey V, Mehra NK, Lodhi N, Nahar M, Mishra DK, et al. Carbohydrate-conjugated multiwalled carbon nanotubes: development and characterization. Nanomedicine 2009;5:432-42.

96. Wang J, Kawde AN, Jan MR. Carbon-nanotube-modified electrodes for amplified enzyme-based electrical detection of DNA hybridization. Biosens Bioelectron 2004;20:995-1000.

97. Vashist SK, Zheng D, Pastorin G, Al-Rubeaan K, Luong JHT, Sheu FS. Delivery of drugs and biomolecules using carbon nanotubes. Carbon 2011;49:4077-97.

98. Mu Q, Liu W, Xing Y, Zhou H, Li Z, Zhang Y, et al. Protein binding by functionalized multiwalled carbon nanotubes is governed by the surface chemistry of both parties and the nanotube diameter. J Phys Chem C 2008;112:3300-7.

99. Ezzati Nazhad Dolatabadi J, Omidi Y, Losic D. Carbon nanotubes as an advanced drug and gene delivery nanosystem. Curr Nanosci 2011;7:297-314

100. Raffa V, Ciofani G, Vittorio O, Riggio C, Cuschieri A Physicochemical properties affecting cellular uptake of carbon nanotubes. Nanomedicine 2010;5:89-97.

101. Bianco A, Kostarelos K, Partidos CD, Prato M. Biomedical applications of functionalised carbon nanotubes. Chem Commun 2005;7:571-7.

102. Kam NWS, Liu Z, Dai H. Carbon nanotubes as intracellular transporters for proteins and DNA: an investigation of the uptake mechanism and pathway. Angew Chem 2006;118:591-5.

103. Porter AE, Gass M, Muller K, Skepper JN, Midgley PA, Welland $\mathrm{M}$. Direct imaging of single-walled carbon nanotubes in cells. Nat Nanotechnol 2007;2:713-7.

104. Sheikhpour M, Golbabaie A, Kasaeian A. Carbon nanotubes: a review of novel strategies for cancer diagnosis and treatment. Mater Sci Eng Proc Conf 2017;76:1289-304.

105. Raffa V, Ciofani G, Nitodas S, Karachalios T, D’Alessandro D, Masini $\mathrm{M}$, et al. Can the properties of carbon nanotubes influence their internalization by living cells? Carbon 2008;46:1600-10.

106. Shvedova AA, Kapralov AA, Feng WH, Kisin ER, Murray AR Mercer RR, et al. Impaired clearance and enhanced pulmonary inflammatory/fibrotic response to carbon nanotubes in myeloperoxidase-deficient mice. PloS One 2012;7:e30923.

107. Shvedova AA, Pietroiusti A, Fadeel B, Kagan VE. Mechanisms of carbon nanotube-induced toxicity: focus on oxidative stress Toxicol Appl Pharmacol 2012;261:121-133.

108. Kagan VE, Konduru NV, Feng W, Allen BL, Conroy J, Volkov Y, et al. Carbon nanotubes degraded by neutrophil myeloperoxidase induce less pulmonary inflammation. Nat Nano 2010;5:354-9.

109. Pacurari M, Yin XJ, Zhao J, Ding M, Leonard SS, Schwegler-Berry $\mathrm{D}$, et al. Raw single-wall carbon nanotubes induce oxidative stress and activate MAPKs, AP-1, NF- $\kappa \mathrm{B}$, and Akt in normal and malignant human mesothelial cells. Environ Health Perspect 2008;116:1211.

110. Jacobsen NR, Pojana G, White P, Møller P, Cohn CA, Smith Korsholm K, et al. Genotoxicity, cytotoxicity, and reactive oxygen species induced by single-walled carbon nanotubes and C60 fullerenes in the FE1-Muta ${ }^{\mathrm{TM}}$ Mouse lung epithelial cells. Environ Mol Mutagen 2008;49:476-87. 
111. Uhrich KE, Cannizzaro SM, Langer RS, Shakesheff KM. Polymeric systems for controlled drug release. Chem Rev 1999;99:3181.

112. Kostarelos K. Rational design and engineering of delivery systems for therapeutics: biomedical exercises in colloid and surface science. Adv Colloid Interface Sci 2003;106:147-68.

113. Jain AK, Kumar Mehra N, Lodhi N, Dubey V, Mishra DK, Jain PK, et al. Carbon nanotubes and their toxicity. Nanotoxicology 2007; 1:167-97.

114. Huczko A, Lange H. Carbon nanotubes: experimental evidence for a null risk of skin irritation and allergy. Fullerene Sci Technol 2001;9:247-50.

115. Huczko A, Lange $H$, Bystrzejewski $M$, Baranowski $P$, Grubek-Jaworska H, Nejman P, et al. Pulmonary toxicity of 1-D nanocarbon materials. Fullerenes Nanotubes Carbon Nanostruct 2005;13:141-5.

116. Warheit DB, Laurence B, Reed KL, Roach D, Reynolds G, Webb T. Comparative pulmonary toxicity assessment of single-wall carbon nanotubes in rats. Toxicol Sci 2004;77:117-25.

117. Pantarotto D, Singh R, McCarthy D, Erhardt M, Briand JP, Prato $\mathrm{M}$, et al. Functionalized carbon nanotubes for plasmid DNA gene delivery. Angew Chem 2004;116:5354-8.

118. Muller J, Huaux F, Moreau N, Misson P, Heilier JF, Delos M, et al. Respiratory toxicity of multi-wall carbon nanotubes. Toxicol Appl Pharmacol 2005;207:221-31.

119. Mehra NK, Jain AK, Lodhi N, Raj R, Dubey V, Mishra D, et al. Challenges in the use of carbon nanotubes for biomedical applications. Crit Rev Ther Drug Carrier Syst 2008;25:169.

120. Lovat V, Pantarotto D, Lagostena L, Cacciari B, Grandolfo M, Righi $\mathrm{M}$, et al. Carbon nanotube substrates boost neuronal electrical signaling. Nano Lett 2005;5:1107-10.

121. Sitharaman B, Shi X, Tran LA, Spicer PP, Rusakova I, Wilson LJ, et al. Injectable in situ cross-linkable nanocomposites of biodegradable polymers and carbon nanostructures for bone tissue engineering. J Biomater Sci Polym Ed 2007;18:655-71.

122. Keefer EW, Botterman BR, Romero MI, Rossi AF, Gross GW. Carbon nanotube coating improves neuronal recordings. Nat Nanotechnol 2008;3:434-9.

123. Gulyaev AE, Gelperina SE, Skidan IN, Antropov AS, Kivman GY, Kreuter J. Significant transport of doxorubicin into the brain with polysorbate 80-coated nanoparticles. Pharm Res 1999; 16:1564-9.

124. VanHandel M, Alizadeh D, Zhang L, Kateb B, Bronikowski M, Manohara $\mathrm{H}$, et al. Selective uptake of multi-walled carbon nanotubes by tumor macrophages in a murine glioma model. J Neuroimmunol 2009;208:3-9.

125. Kateb B, Van Handel M, Zhang L, Bronikowski MJ, Manohara H, Badie B. Internalization of MWCNTs by microglia: possible application in immunotherapy of brain tumors. Neuroimage 2007;37:S9-S17.

126. Zhang Y, Bai Y, Yan B. Functionalized carbon nanotubes for potential medicinal applications. Drug Discovery Today 2010;15:428-35.
127. Irineu JAF, Marsi TC, Santos TG, Maria A, Santo E, Rangel JL, et al. Characterization and bioactivity study of nano-hydroxyapatite on superhydrophilic vertically aligned carbon nanotubes using optical techniques. Proc of SPIE; 2012. p. 82321K-1.

128. Singh R, Mehra NK, Jain V, Jain NK. Gemcitabine-loaded smart carbon nanotubes for effective targeting to cancer cells. J Drug Targeting 2013;21:581-9.

129. Zheng M, Jagota A, Strano MS, Santos AP, Barone P, Chou SG, et al. Structure-based carbon nanotube sorting by sequencedependent DNA assembly. Science 2003;302:1545-8.

130. Bhirde AA, Patel V, Gavard J, Zhang G, Sousa AA, Masedunskas $A$, et al. Targeted killing of cancer cells in vivo and in vitro with EGF-directed carbon nanotube-based drug delivery. ACS Nano 2009;3:307-16

131. Wang $\mathrm{H}$, Wang J, Deng $\mathrm{X}$, Sun $\mathrm{H}$, Shi $\mathrm{Z}, \mathrm{Gu} \mathrm{Z}$, et al. Biodistribution of carbon single-wall carbon nanotubes in mice. J Nanosci Nanotechnol 2004;4:1019-24.

132. Kam NWS, Dai H. Carbon nanotubes as intracellular protein transporters: generality and biological functionality. J Am Chem Soc 2005;127:6021-6.

133. Liu Z, Winters M, Holodniy M, Dai H. siRNA delivery into human t cells and primary cells with carbon-nanotube transporters. Angew Chem Int Ed 2007;46:2023-7.

134. Sobhani Z, Dinarvand R, Atyabi F, Ghahremani M, Adeli M. Increased paclitaxel cytotoxicity against cancer cell lines using a novel functionalized carbon nanotube. Int J Nanomed 2011;6:705.

135. Chen M, Song X, Lv Q, Gan Z, Liu S. Bonding of carbon nanotubes onto microelectrodes by localized induction heating. Sens Actuators A 2011;170:202-6.

136. Huang $\mathrm{H}$, Yuan $\mathrm{Q}$, Shah IS, Misra RD. A new family of folatedecorated and carbon nanotube-mediated drug delivery system: synthesis and drug delivery response. Adv Drug Delivery Rev 2011;63:1332-9.

137. Pruthi J, Mehra NK, Jain NK. Macrophages targeting of amphotericin B through mannosylated multiwalled carbon nanotubes. J Drug Target 2012;20:593-604.

138. Ji Z, Lin G, Lu Q, Meng L, Shen X, Dong L, et al. Targeted therapy of SMMC-7721 liver cancer in vitro and in vivo with carbon nanotubes based drug delivery system. J Colloid Interface Sci 2012;365:143-9.

139. Elhissi A, Ahmed W, Dhanak VR, Subramani K. Carbon Nanotubes in Cancer Therapy and Drug Delivery 2012:347-63. http://dx.doi.org/10.1155/2012/837327

140. Lodhi N, Mehra NK, Jain NK. Development and characterization of dexamethasone mesylate anchored on multi walled carbon nanotubes. J Drug Target 2013;21:67-76.

141. Aliev AE, Oh J, Kozlov ME, Kuznetsov AA, Fang S, Fonseca AF, et al. Giant-stroke, superelastic carbon nanotube aerogel muscles. Science 2009;323:1575-8.

\section{How to cite this article}

- Anamika Sahu, Aviral Jain, Arvind Gulbake. The role of carbon nanotubes in nanobiomedicines. Int J Pharm Pharm Sci 2017;9(6):235-251. 